Vaccaro, A. S., J. Filloy, and M. I. Bellocq. 2019. What land use better preserves taxonomic and functional diversity of birds in a grassland biome? Avian Conservation and Ecology 14(1):1. https://doi.org/10.5751/ACE-01293-140101

Copyright (C) 2019 by the author(s). Published here under license by the Resilience Alliance.

Research Paper

\title{
What land use better preserves taxonomic and functional diversity of birds in a grassland biome?
}

\author{
Anahi S. Vaccaro ${ }^{1}$, Julieta Filloy ${ }^{1}$ and M. Isabel Bellocq ${ }^{1}$ \\ ${ }^{1}$ Departamento de Ecología, Genética y Evolución, IEGEBA (CONICET-UBA), Facultad de Ciencias Exactas y Naturales, \\ Universidad de Buenos Aires
}

\begin{abstract}
The Pampean grassland in South America has been almost completely transformed by human activities and is one of the biomes at the highest conservation risk. Although several land uses are developed in temperate grasslands, studies comparing their impact on bird taxonomic and functional diversity are still missing. We determined what habitat type resulting from human land uses better preserves the assemblage of birds and their functional traits that occur in protected grasslands. We compared taxonomic and functional diversity between protected grasslands and cattle pastures, crop fields, tree plantations, and urban settlements. We surveyed birds and environmental variables in the 5 habitat types using point counts and selected 11 traits to estimate functional diversity. We performed principal component analysis to explore environmental differences between habitat types, ANOVA to compare taxonomic and functional diversity, nonmetric multidimensional scaling to explore relationships between habitat type characteristics and species traits, and similarity percentage analysis to find the bird functional traits that contributed the most to differentiate habitat types. Bird composition and functional diversity in cattle pastures was the most similar to that of protected areas but showed no significant differences with crop fields. In cattle pastures, crop fields, and protected areas, the most frequent species traits were related to narrow ranges and high vulnerability to extinction, whereas urban settlements included traits covering wide ranges or related to impervious areas. When compared with protected areas, land conversion into cattle pastures and some types of agricultural lands resulted in a lower loss of bird species and functional diversity than conversion into tree plantations or urbanized areas. Approximately $35 \%$ of species found in protected areas were not recorded in any of the other habitat types. Therefore, we emphasize the need to protect the native habitat. Our findings help with land use planning in the Pampas and other temperate grasslands.
\end{abstract}

\section{Quelle utilisation des terres préserve au mieux la diversité taxonomique et fonctionnelle des oiseaux dans un biome de prairie?}

RÉSUMÉ. Les prairies pampéennes d'Amérique du Sud ont été presque complètement transformées par les activités humaines et constituent l'un des biomes les plus menacés en matière de conservation. Bien que plusieurs utilisations des terres soient développées dans les prairies tempérées, des études comparant leurs impacts sur la diversité taxonomique et fonctionnelle des oiseaux manquent encore. Nous avons déterminé quel type d'habitat résultant de l'utilisation des terres par l'homme préservait au mieux l' 'ensemble des oiseaux et leurs caractéristiques fonctionnelles qui se trouvent dans les prairies protégées. Nous avons comparé la diversité taxonomique et fonctionnelle entre les prairies protégées, les pâturages, les champs cultivés, les plantations d'arbres, et les agglomérations urbaines. Nous avons étudié les oiseaux et les variables environnementales dans les 5 types d'habitat en utilisant des dénombrements ponctuels et en sélectionnant 11 caractères pour estimer la diversité fonctionnelle. Nous avons effectué une analyse en composantes principales pour explorer les différences environnementales entre les types d'habitat, une ANOVA pour comparer la diversité taxonomique et fonctionnelle, une échelle multidimensionnelle non métrique pour explorer les relations entre les caractéristiques des types d'habitat et les traits des espèces, et une analyse du pourcentage de similarité pour trouver les traits fonctionnels des oiseaux qui contribuent le plus à différencier les types d'habitat. La composition en oiseaux et la diversité fonctionnelle dans les pâturages de bovins étaient les plus similaires à celles des aires protégées mais ne présentaient pas de différences significatives avec les champs cultivés. Dans les pâturages, les champs, et les prairies protégées, les caractères les plus fréquents étaient liés à des aires de répartition étroites, et à une forte vulnérabilité à l'extinction, alors que les agglomérations urbaines comprenaient des caractères couvrant de vastes aires de répartition, ou liées à des zones imperméables. Par rapport aux zones protégées, la conversion des terres en pâturages pour bovins et certains types de terres agricoles, a entraîné une perte moins importante d'espèces d'oiseaux et de diversité fonctionnelle que la conversion en plantations d'arbres ou en zones urbanisées. Environ 35\% des espèces présentes dans les prairies protégées ne sont répertoriées dans aucun autre type d'habitat. En conséquent, nous insistons sur la nécessité de protéger l'habitat naturel. Nos conclusions aident à planifier l'utilisation des terres dans la Pampa et autres prairies tempérées.

Key Words: anthropogenic habitats; Argentina; birds; functional diversity; grasslands; taxonomic diversity

Address of Correspondent: Anahí S. Vaccaro, Departamento de Ecología, Genética y Evolución, IEGEBA (CONICET-UBA), Facultad de Ciencias Exactas y Naturales, Universidad de Buenos Aires, Ciudad Universitaria, Pabellón 2, Piso 4, C1428EHA Buenos Aires, Argentina, anahivaccaro@ege.fcen.uba.ar 


\section{INTRODUCTION}

Habitat conversion attributable to human activities is a major cause of global biodiversity loss (Sala et al. 2000, Foley et al. 2005), especially in temperate climates (Millennium Ecosystem Assessment 2005). Grasslands are one of the most threatened terrestrial ecosystems in the world because of both the replacement of native habitat by agricultural lands and the existence of relatively few protected areas (Hoekstra et al. 2005, Henwood 2010). In South America, the Pampean grassland is an extraordinarily productive land that has been almost completely transformed by human activities over the 20th century (León et al. 1984, Paruelo et al. 2006, Vega et al. 2009), and it is considered at high conservation risk because of agricultural development (Soriano et al. 1991, Sala et al. 2000, Viglizzo et al. 2001). The grassland transformation process in the Pampas started in the 16 th century with the introduction of domestic cattle brought by Europeans (Hall et al. 1992). After the 1950s, the native vegetation was rapidly and highly degraded and fragmented because of increasing intensive agriculture (Bilenca and Miñarro 2004), and the land was converted primarily into crop fields and cattle pastures (Facelli et al. 1989, Miñarro and Bilenca 2008). Also, urban settlements were established or further developed in the region, and financial incentives promoted commercial plantations of exotic eucalypt (Eucalyptus spp.) and pine (Pinus spp.; Brizuela et al. 2003, Galindo Leal and de Gusmão Câmara 2003). Currently, the Pampean region shows an agricultural matrix and supports one of the highest rates of land use change in the world (Paruelo et al. 2006, Baldi and Paruelo 2008). Previous studies have shown that the loss and degradation of grasslands because of anthropogenic land use have negative effects on terrestrial vertebrates (Ceballos et al. 2010, Davidson et al. 2012), including birds (Goriup 1988, Stotz et al. 1996, Donald et al. 2006, Askins et al. 2007). In the Pampas, there is evidence that the populations of several resident grassland birds have declined markedly (Azpiroz et al. 2012).

An increasing number of studies have analyzed biodiversity in both native and anthropogenic habitats and landscapes, resulting from different human land uses, to better understand the changes in natural communities caused by human activities that modify large extensions of land (e.g., Renjifo 2001, Benton et al. 2003). However, the biodiversity in natural and anthropogenic habitats at the regional or interregional scales has been less explored (but see Allen and O'Connor 2000, Catterall et al. 2010, Filloy et al. 2015), and studies considering several land uses are even more infrequent and are conducted mostly in forest biomes (Petit et al. 1999, Tylianakis et al. 2006, Zurita and Bellocq 2012, Phillips et al. 2017). Furthermore, few studies have analyzed how land use changes the assemblage of species and their functional traits (Luck et al. 2013, Bregman et al. 2016).

Previous studies conducted in many ecosystems including grasslands have documented the impacts of land use on bird taxonomic richness (e.g., Chamberlain and Fuller 2000, Verhulst et al. 2004, Waltert et al. 2004, Piha et al. 2007) and community composition (e.g., Perkins et al. 2000, McMaster and Davis 2001, Bennett et al. 2004). In recent years, however, species are also perceived as a collection of individuals with phenotypic and behavioral traits that determine where they can occur, how they interact with each other, and the species contribution to ecosystem functioning (McGill et al. 2006). Thus, researchers have become increasingly interested in the diversity of species traits related to life history, i.e., clutch size and body mass, and ecosystem functioning, i.e., distance of seeds dispersed and predation rate. Functional diversity was first defined by Tilman (2001) as the value and range of species traits that influence the way ecosystems operate, and later expanded by Petchey et al. (2004) to represent the diversity of traits related to life history and functions. The study of biodiversity is not limited to species richness and has incorporated functional diversity to understand the responses of species to environmental changes (Schleuter et al. 2010, Cadotte et al. 2011), the process of assemblage formation (Petchey et al. 2007, Cornwell and Ackerly 2009), and how species diversity relates to ecosystem function (Norberg et al. 2001, Petchey et al. 2004, Suding et al. 2008). Furthermore, by measuring and understanding functional diversity, we can make better conservation and restoration decisions (Cadotte et al. 2011); for example, we can predict functional community structure to anticipate the potential loss of ecosystem services and detect disturbance impacts before species loss and extinctions occur (Cardinale et al. 2012, Mouillot et al. 2013). Environmental conditions and anthropogenic disturbances influence functional diversity (Vandewalle et al. 2010, Villéger et al. 2010, Luck et al. 2013), which is particularly relevant for birds because they play a wide variety of ecological functions and are sensitive to habitat changes (Cody 1985, Sekercioglu 2006).

The richness and composition of bird assemblages, hereafter referred to as taxonomic diversity, in a given anthropogenic habitat type depend primarily on how land use alters the natural environmental filters imposed on the regional species pool. Environmental filters are abiotic conditions and resources that exclude species with nonviable physiological or ecological limits, defined by functional traits, to enter or persist in a community (Mayfield et al. 2010, Kraft et al. 2015). Thus, it is expected that different anthropogenic habitat types, such as crop fields, tree plantations, and urban centers, alter environmental filters in different ways, resulting in different biological assemblages. For example, in grassland ecosystems, the soil temperature is lower in tree plantations but higher in cattle pastures than in the native habitat; similarly, the soil compaction is higher in cattle pastures but lower in crop fields, promoting different changes in biological communities (Hobbs et al. 2006, Mayfield et al. 2006, Ricotta et al. 2008).

The resulting assemblage in each anthropogenic habitat type will be composed of species sharing functional traits that make them tolerant to the new abiotic conditions and resource availability (Kraft et al. 2015). Habitat types that are very different from the natural habitat lead to major changes of the natural environmental filters. Therefore, our working hypothesis is that the detrimental effects of land use on native biological communities depend on the environmental similarity between the native and the human-modified habitats (Filloy et al. 2010, DinizFilho et al. 2011). Because birds are sensitive to vegetation structure (MacArthur and MacArthur 1961), it is expected that habitat types preserving the vegetation structure of the natural habitat, at least partially, will better conserve the taxonomic and functional diversity of the native regional pool (Gascon et al. 1999, Zurita and Bellocq 2010). In contrast, it is expected that habitat types that drastically change features of the original habitat will lead to major loss of native species richness and 
functional diversity (Naeem and Wright 2003, Flynn et al. 2009, Mayfield et al. 2010). To give useful conclusions about changes in biodiversity and ecosystem functions and solve conservation problems, current research encourages the simultaneous study of different facets of diversity (Naeem et al. 2012). Although several land uses are developed in temperate grasslands, studies comparing simultaneously their impact on taxonomic and functional diversity are still missing. Understanding the response of taxonomic and functional diversity to several anthropogenic habitat types in grasslands such as the Pampas will contribute to land use planning and wildlife conservation.

We compare for the first time in temperate grasslands, taxonomic diversity, i.e., species richness and species composition similarity, and functional diversity, i.e., bird trait diversity and trait composition similarity, between protected areas (grasslands considered as the reference habitat type) and four extended anthropogenic habitat types, i.e., crop fields, cattle pastures, tree plantations, and urban settlements, to find out what habitat type better preserves the assemblage of selected bird species and functional traits that occur in protected grasslands. Based on our working hypothesis, we posited that, environmentally, cattle pastures would be the most similar to natural grasslands, because they have a monostratified vegetation structure, i.e., the herbaceous stratum, and relatively low human intervention. Although crop fields are also monostratified, they are exposed to mechanical and chemical treatments that deeply influence vegetation structure and species composition. We also hypothesized that tree plantations and urban settlements would be the most different from natural grasslands because of the high canopy and impervious coverage, respectively. Then, we predicted that species richness and functional diversity of birds would be the highest in cattle pastures followed by crop fields, tree plantations, and urban settlements. Furthermore, we predicted that habitats showing less drastic differences with protected areas, such as cattle pastures, would have the highest taxonomic and functional similarities. We also explored relationships between different habitat type characteristics and species traits and expected that each habitat type would have a set of species with traits related to the vegetation structure; for example, we predicted that species with generalist traits, such as omnivorous diet, nesting in various sites, or cosmopolitan distribution, would be more frequent in habitat types with the highest environmental differences with the natural habitat. To test our predictions, we first compared environmental similarity, species richness, and functional diversity between protected grasslands and the different anthropogenic habitat types. Then, we compared taxonomic and functional similarities among habitat types; and finally, we explored the ordination of habitat types based on species traits.

\section{METHODS}

\section{Study design}

To analyze the relationship of taxonomic and functional diversity with habitat type, we surveyed birds and registered environmental variables in protected grasslands and 4 anthropogenic habitat types, i.e., cattle pastures, crop fields, tree plantations, and urban settlements, resulting from different land uses in the Pampean region of Argentina. We selected a total of 27 study sites (Fig. 1),
6 sites per anthropogenic habitat type and 3 in protected areas, the only natural reserves available in the region. Each study site was approximately 20 ha in size, and sites were at least $2 \mathrm{~km}$ apart to ensure different local bird communities. We recorded vegetation coverage and stratification to characterize the habitat at each study site and to estimate the environmental similarity between protected grasslands and each anthropogenic habitat type. We selected 11 functional traits and estimated functional diversity and functional similarity for each study site. Selected traits were as follows: diet, foraging substrate, body size, clutch size, nesting habitats, migratory status, amplitude of habitat use, primary habitat, sensitivity to human disturbance, abundance, and distribution (for more details, see Appendix 1).

Fig. 1. Location of the 27 sampling sites (different symbols for each habitat type) in the Pampean region of Argentina (light gray).

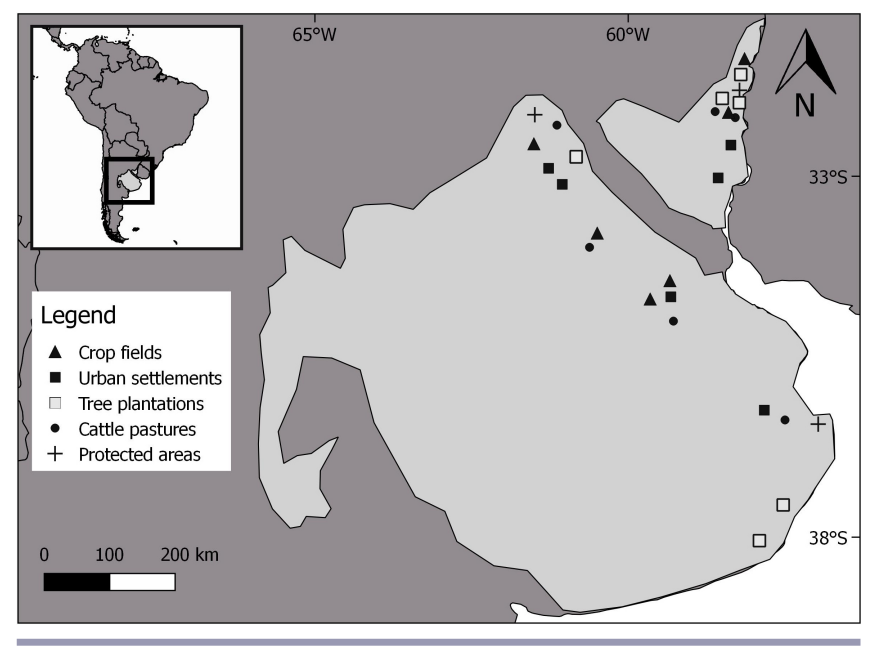

\section{Study area and land uses}

The Pampean region covers approximately $444,990 \mathrm{~km}^{2}\left(30^{\circ} 48^{\prime}\right.$ $5^{\prime \prime}$ to $38^{\circ} 58^{\prime} 47^{\prime \prime}$ from $\mathrm{N}$ to $\mathrm{S}$ and $56^{\circ} 42^{\prime} 25^{\prime \prime}$ to $66^{\circ} 33^{\prime} 37^{\prime \prime}$ from $\mathrm{W}$ to E). It has temperate climate, with mean annual temperature and precipitation ranging between $13^{\circ} \mathrm{C}$ and $17^{\circ} \mathrm{C}$ and between 800 and $1100 \mathrm{~mm} / \mathrm{yr}$, respectively. The region was originally dominated by grasses such as Paspalum, Axonopus, Stipa, Bromus, and Piptochaetium (Landi et al. 1987), and trees were absent; however, currently, small and isolated woodlots are often found in cattle shelters, windbreaks, farms, or towns.

We selected the main land uses of the region, i.e., agriculture, livestock, forestry, and urbanization, that resulted in the 4 most extended habitat types: crop fields, cattle pastures, tree plantations, and urban settlements. Crop fields represented the main crops produced in the region: soybean, wheat, and corn. Cattle pastures were areas with spontaneous vegetation, i.e, no seeded pastures, composed primarily of grasses and secondarily of herbaceous dicots, supporting a moderate grazing pressure of 0.7-0.6 animals/ha. Tree plantations were commercial eucalypt plantations (mainly Eucalyptus grandis), 7 to 10 years of age, used primarily for lumber and board production. Urban settlements were typical cities of the region holding 14,000-60,000 inhabitants, where the impervious area, i.e, buildings, houses, and 
paved roads, increased from the rural to the core urban zone (Garaffa et al. 2009). The 3 protected areas were El Palmar National Park (82 km²; 31 $\left.51^{\prime} 11^{\prime \prime} \mathrm{S}, 58^{\circ} 19^{\prime} 2^{\prime \prime} \mathrm{W}\right)$, Campos del Tuyú National Park ( $\left.30 \mathrm{~km}^{2} ; 36^{\circ} 21^{\prime} 00^{\prime \prime} \mathrm{S}, 56^{\circ} 52^{\prime} 00^{\prime \prime} \mathrm{W}\right)$, and the Federico Wildermuth private natural reserve $\left(13 \mathrm{~km}^{2} ; 32^{\circ} 00^{\prime} 33^{\prime \prime}\right.$ $\left.\mathrm{S}, 61^{\circ} 24^{\prime} 30^{\prime \prime} \mathrm{W}\right)$.

\section{Bird survey and environmental variables}

In each of the selected study sites, we established 10 observation points systematically from a random starting point. All points were located at least $200 \mathrm{~m}$ away from a different habitat type. The shortest distance between observation points was $150 \mathrm{~m}$ because that is the minimum distance recommended to avoid double counting (Bibby et al. 1998). In urban areas, points were located every 2 blocks $(200 \mathrm{~m})$ in the city centers, at the street intersections, and at least 1 block apart from green areas. Birds were surveyed using the point-count technique with a fixed 50-m radius (DeGraaf et al. 1991, Ralph et al. 1996). Observation points were visited once during the breeding season (September to November), from sunrise to $4 \mathrm{~h}$ after sunrise on sunny days with calm wind. At each observation point, all birds seen or heard were identified and recorded during a 5-min period. To increase reliability of species identification, bird surveys were made simultaneously by 2 trained independent observers at each observation point, and bird songs were recorded with a digital recorder (Zoom H4next Handy Recorder) at all observation points during the 5-min period. Identities for recorded songs were verified by comparing them with published recordings (Xenocanto Foundation 2018). Birds flying overhead were disregarded.

Environmental variables related to soil and vegetation coverage and structure were measured at each observation point: percentage coverage of trees, shrubs, herbaceous vegetation (including grasses, dicots, and crops), bare soil, leaf litter, and impervious areas and grass height. We considered crops as the herbaceous vegetation stratum because our objective was to conduct a general characterization of vegetation structure. At each observation point, we randomly established three $1-\mathrm{m}^{2}$ quadrats within an area of $50-\mathrm{m}$ radius centered at each observation point and visually estimated coverage of shrubs, herbs, bare soil, and leaf litter following Braun-Blanquet (Mueller-Dombois and Ellenberg 1974). Values from the 3 quadrats were averaged for each observation point. To estimate tree coverage and impervious areas, we used satellite images, establishing a circle of 50-m radius centered at each observation point. For each environmental variable, values obtained from the 10 observation points were averaged for each study site.

\section{Selection of functional traits}

We selected 11 functional traits, and their categories, related to species life history, based on previous studies on bird functional diversity or responses to habitat replacement (Cofre et al. 2007, Feeley et al. 2007, Petchey et al. 2007, López-Lanús et al. 2008, Flynn et al. 2009, Vandewalle et al. 2010, Leveau 2013, Corbelli et al. 2015). We considered ecological traits, e.g., main foraging substrate, habitat amplitude, sensitivity to human disturbance, and distribution, and life-history traits, e.g., diet, body mass, and clutch size (see Table A1.1 in Appendix 1). The selected traits are relevant to understand how bird species may respond to environmental changes and how each species affects ecosystem function (Luck et al. 2013). Following the usual protocol for standardization of the trait matrix (e.g., Holmes et al. 1979, Jaksić and Medel 1990, Petchey and Gaston 2002), all traits were treated as categorical, and each category was binary: we assigned 0 or 1 depending on whether the species presented each category of the trait. Traits with multiple states, such as diet, were subdivided, and each state was treated as a single binary trait. For example, if a species feeds primarily on insects and seeds, we assigned 1 to both "insectivore" and "granivore," and 0 to the rest of the feeding categories. All trait categories were mutually exclusive, i.e., only one category of each trait was 1, except "diet," "foraging substrate," and "nesting habitat." Trait information was taken from Narosky et al. (2010), De la Peña (2013, 2016), Del Hoyo et al. (2016), BirdLife International (2018), and López-Lanús et al. (2008).

\section{Data analyses}

Based on survey data and functional trait values, we built 3 matrices: (1) sites by environmental variables, (2) sites by species abundance, and (3) species by traits. To build the site by environmental variables matrix, we calculated the average value, from the 10 observation points, of each environmental variable at each study site, obtaining a matrix with $27 \times 7$ dimensions. The site by species abundance matrix was built by adding species abundance recorded at the 10 observation points for each study site, obtaining a matrix with $27 \times 92$ dimensions because we recorded a total of 92 bird species. Finally, the species by traits matrix had $92 \times 55$ dimensions because we selected a total of 55 trait categories for each species (see Table A1.1 in Appendix 1 and Table A4.1 in Appendix 4).

\section{Environmental variables and taxonomic and functional diversity}

To explore environmental differences between habitat types, we performed a principal component analysis (PCA) on environmental variables at each sampling site (Legendre and Legendre 2012) using the "rda" function of the "vegan" package (Oksanen et al. 2016, R Core Team 2018). Because environmental variables were measured at different scales and units, we standardized them using the standard deviation to render scalefree and dimensionless variables (Legendre and Legendre 1998).

Species richness was obtained by pooling the 10 point counts and calculating the number of different bird species present in each study site (Magurran 2004). We used the "diversityresult" function in the R package "BiodiversityR" (Kindt and Coe 2005, $\mathrm{R}$ Core Team 2018). To estimate functional diversity (FD), we used the multidimensional functional dispersion index (FDis) developed by Laliberté and Legendre (2010). FDis is the mean distance of the multidimensional trait space of individual species to the centroid of all species, and it allows for the use of relative abundances. This index is unaffected by species richness, is not strongly influenced by outliers, can include any number and type of traits, and can be computed from any distance or dissimilarity measure (Anderson et al. 2006). To estimate FDis, we first calculated the species by species distance matrix from the species by traits original matrix using the Jaccard method ("vegdist" function in the R package "vegan") because it is suitable for categorical data and omits double zeros (Legendre and Legendre 2012, R Core Team 2018). Then, we calculated FDis for each study site with the "FD" package based on the species by species distance and the sites by species matrices (Laliberté and Legendre 
Fig. 2. Biplot representing the first (PC1) and second (PC2) axes of principal component analysis, showing ordination of sites according to environmental variables measured in cattle pastures, crop fields, urban settlements, protected areas, and tree plantations. Environmental variables are percentage coverage of trees (TREE_STR), shrub (SHRUB_STR), herbs (HERB_STR), bare soil (SOIL_CO), leaf litter (LITT_CO), impervious surface (IMP_CO), and grass height (HERB_HEIGHT).

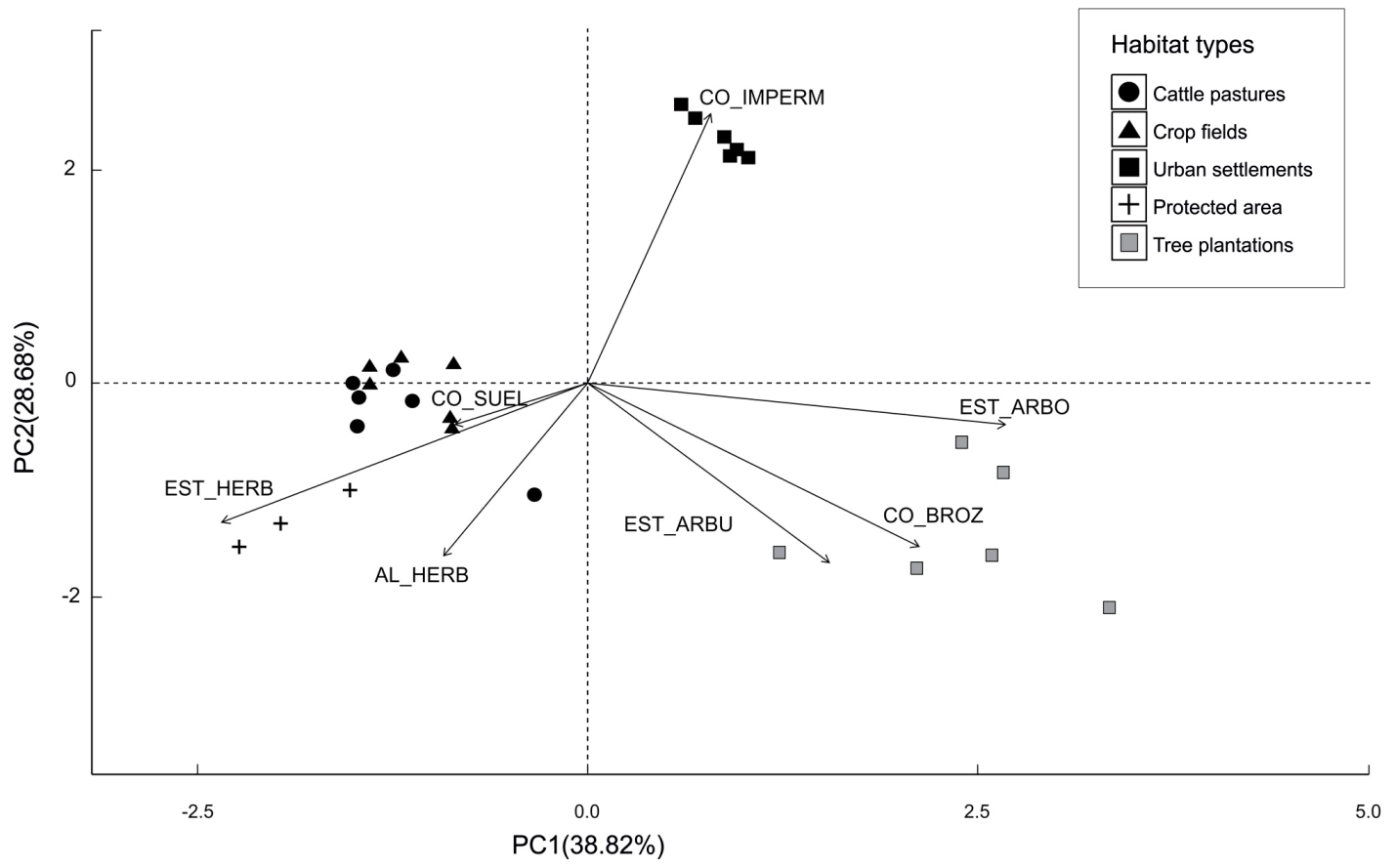

2010, R Core Team 2018). Finally, we tested for significant differences of the species richness and FDis values among habitat types using ANOVA and post hoc multiple comparisons, previously testing assumptions of normality and homogeneity of variances.

We calculated the similarity of bird assemblages between each anthropogenic habitat type and the pool of species recorded in our surveys of protected areas that represent a subset of the regional grassland species pool, based on both species composition and functional traits. For species composition, i.e., taxonomic similarity, we obtained the Jaccard index of similarity among study sites, i.e., 1 minus dissimilarity, using the "betapart" R package (Baselga and Orme 2012, R Core Team 2018). To estimate functional similarity, we first calculated a functional similarity among species matrix using the Jaccard similarity measure in the R package "vegan." Second, we used the functional similarity matrix and the unweighted pair-group clustering method using arithmetic averages to build a dendrogram that represented the trait similarity between species (Petchey and Gaston 2002). Third, we used the sites by species presence/absence matrix and the trait similarity dendrogram to calculate the functional Sorensen's index (FSor). FSor is an indicator of the function shared between two communities (Swenson et al. 2011) and is analog to the phylogenetic metric PhyloSor, which is in the $\mathrm{R}$ package "Picante" (Kembel et al. 2010). The obtained taxonomic and functional similarity values (Jaccard similarity and FSor) were compared among habitat types using ANOVA and post hoc multiple comparisons; assumptions of normality and homogeneity of variance were previously tested.

\section{Bird traits and land uses}

A nonmetric multidimensional scaling (NMDS), with the Horn index in the R package "vegan," was used to ordinate land uses based on the similarity of the functional trait assemblages. We first constructed the sites by traits presence/absence matrix by using the sites by species and the species by traits matrices. NMDS was developed with the "metaMDS" function in the R package "vegan" (Oksanen et al. 2016, R Core Team 2018). This function adds trait scores to the site ordination; to improve the visualization, we show an NMDS for each group of traits, i.e., feeding habits, breeding, habitat use, and vulnerability (see Table A1.1 in Appendix 1).

We used the similarity percentage (SIMPER) analysis to find the bird functional traits that contributed the most to differentiate habitat types (Clarke 1993). The SIMPER function performs pairwise comparisons of groups of sampling units and finds the average contributions of each variable to the average overall dissimilarity, ranking all variables according to the average contribution. We used the sites by traits presence/absence data matrix to perform SIMPER analysis. For each pairwise comparison of habitat types, we selected the top 10 traits that best discriminated between land uses. The total number of traits obtained was 23 , because many of them were repeated in the comparisons; we show these traits in a separate NMDS. 


\section{RESULTS}

In the 27 sites surveyed ( 3 protected areas and 6 of each anthropogenic habitat type), we recorded a total of 2773 individual birds belonging to 93 species: 333 individuals from 46 species in protected areas, 787 individuals representing 50 species in cattle pastures, 392 individuals from 33 species in crop fields, 360 individuals from 34 species in tree plantations, and 901 individuals from 24 species in urban settlements. Approximately $35 \%$ of species found in the protected areas were not recorded in any of the other habitat types (Appendix 3).

The PCA, used to explore environmental differences between habitats, ordered sites by habitat type (Fig. 2). The first and second axes explained $38.8 \%$ and $28.7 \%$ of the variation in environmental variables among sites, respectively. Urban settlements and tree plantations were located at the upper and bottom right quadrants of the biplot, respectively, whereas cattle pastures, crop fields, and protected grasslands were on the left side with the latter taking the bottom quadrant. Protected areas were characterized by high coverage of tall grasses, whereas both cattle pastures and crop fields were characterized by intermediate values of herbaceous plants and bare soil coverage. Tree plantations were associated with high coverage of trees, shrubs, and leaf litter, and urban settlements were associated with impervious areas. Cattle pastures and crop fields were the most similar to protected grasslands.

Protected areas and cattle pastures showed the highest richness values, although with nonsignificant differences with crop fields. Also, we found no difference between species richness in protected areas and tree plantations. Species richness in crop fields and tree plantations was intermediate, and urban settlements showed the lowest values, but with nonsignificant differences with tree plantations and crop fields (Table 1, Fig. 3). Results showed a gradient of decreasing functional diversity (FDis) between habitat types (Fig. 4). Protected areas showed the highest FDis values followed by tree plantations, cattle pastures, and crop fields, although with nonsignificant differences. In urban areas, functional diversity was significantly lower than that in the other habitat types (Table 2, Fig. 4).

Table 1. Multiple comparisons of means (Tukey contrasts) of richness between habitat types. Habitat types are urban settlements (US), cattle pastures (CP), crop fields (CF), tree plantations (TP), and protected areas (PA). $P<0.05$; asterisk $\left(^{*}\right)$ indicates significant differences.

\begin{tabular}{lcc}
\hline \hline Habitat Types Comparison & $t$ Value & $P$ \\
\hline US versus CP & -4.483 & $0.0016^{*}$ \\
US versus CF & -1.546 & 0.5426 \\
US versus PA & -3.661 & $0.0106^{*}$ \\
US versus TP & -1.159 & 0.7716 \\
CP versus CF & -2.937 & 0.0526 \\
CP versus PA & 0.000 & 1.0000 \\
CP versus TP & -3.324 & $0.0227^{*}$ \\
CF versus PA & -2.398 & 0.1516 \\
CF versus TP & -0.386 & 0.9949 \\
TP versus PA & -2.714 & 0.0831 \\
\hline
\end{tabular}

Table 2. Multiple comparisons of means (Tukey contrasts) of functional diversity (FDis) between habitat types. Habitat types are urban settlements (US), cattle pastures (CP), crop fields (CF), tree plantations (TP), and protected areas (PA). $P<0.05$; asterisk (*) indicates significant differences.

\begin{tabular}{lcc}
\hline \hline Habitat Types Comparison & $t$ Value & $P$ \\
\hline US versus CP & -4.467 & $0.0015^{*}$ \\
US versus CF & -3.395 & $0.0194^{*}$ \\
US versus PA & 4.817 & $<0.001^{*}$ \\
US versus TP & 5.327 & $<0.001^{*}$ \\
CP versus CF & -1.072 & 0.8171 \\
CP versus PA & 1.17 & 0.766 \\
CP versus TP & 0.86 & 0.9072 \\
CF versus PA & 2.045 & 0.2762 \\
CF versus TP & 1.932 & 0.3281 \\
TP versus PA & -0.467 & 0.9894 \\
\hline
\end{tabular}

Fig. 3. Averages of species richness values in different habitat types of the Pampean grasslands. Vertical lines show standard deviations. Different letters indicate significant differences $(P<0.05)$ between pairs of habitat types: results of multiple comparisons of means (Tukey contrasts) of richness between habitat types.

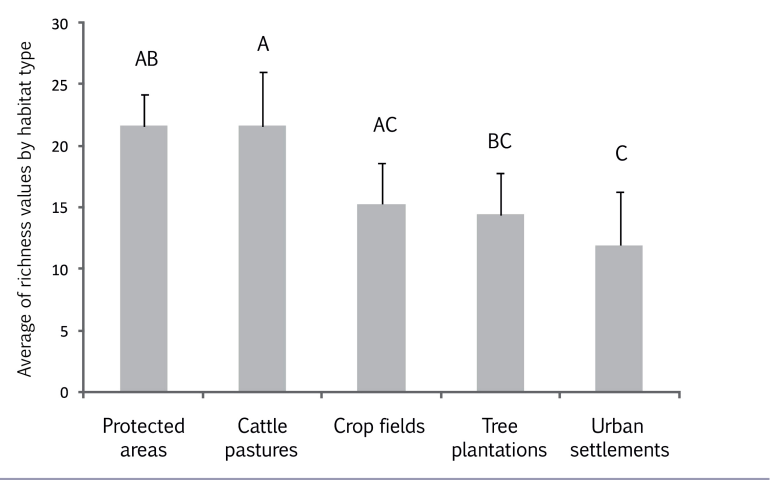

Fig. 4. Averages of functional diversity values (FDis index) in different habitat types of the Pampean grasslands. Vertical lines show standard deviations. Different letters indicate significant differences $(P<0.05)$ between pairs of habitat types: results of multiple comparisons of means (Tukey contrasts) of FDis between habitat types.

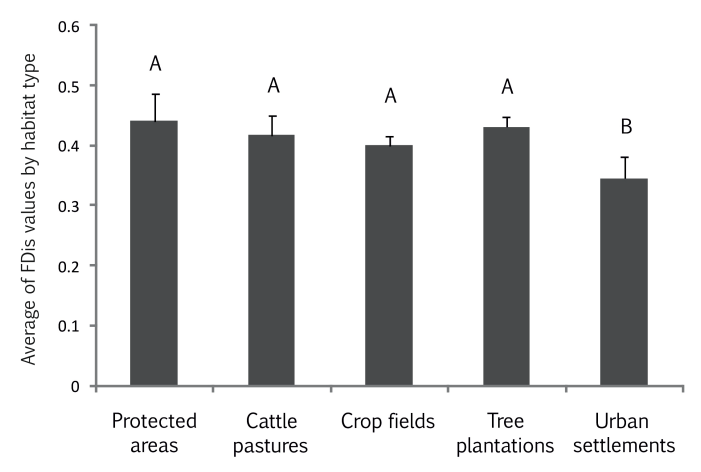


Species composition and functional similarities of birds with respect to protected areas differed between anthropogenic habitat types $\left(F_{3,20}=6.152, P<0.005\right.$ for species composition similarity and $F_{3,20}=10.28, P<0.0003$ for functional similarity; Tables 3 and 4). Cattle pastures tended to be more similar to protected areas than crop fields, although the difference was nonsignificant, followed by tree plantations and urban settlements. Differences in 1 minus Jaccard and FSor values between tree plantations and crop fields were not significant. Species composition similarity between urban settlements and protected areas was the lowest, although not significantly different from crop fields and tree plantations. Functional similarity in urban settlements was the lowest and significantly differed from cattle pastures and crop fields, but it was not significantly different from tree plantations (Figs. 5 and 6).

Table 3. Results of multiple comparisons of means (Tukey contrasts) of species composition similarity (1 - Jaccard) between habitat types and protected areas. Acronyms are as given in Table 1. $P<0.05$ indicates significant differences.

\begin{tabular}{lcc}
\hline \hline Comparisons & $t$ Value & $P$ \\
\hline CP-PA versus CF-PA & -1.590 & 0.4061 \\
CP-PA versus US-PA & -3.979 & $0.0039^{*}$ \\
CP-PA versus TP-PA & -3.124 & $0.0253^{*}$ \\
CF-PA versus US-PA & 2.389 & 0.1117 \\
CF-PA versus TP-PA & 1.534 & 0.4371 \\
TP-PA versus US-PA & -0.855 & 0.8276 \\
\hline
\end{tabular}

Table 4. Results of multiple comparisons of means (Tukey contrasts) of functional similarity (FSor) between habitat types and protected areas. Acronyms are as given in Table 1. $P<0.05$ indicates significant differences.

\begin{tabular}{lcc}
\hline \hline Comparisons & $t$ Value & $P$ \\
\hline CP-PA versus CF-PA & 1.892 & 0.2626 \\
CP-PA versus US-PA & 5.444 & $<0.001^{*}$ \\
CP-PA versus TP-PA & 2.888 & $0.04164^{*}$ \\
CF-PA versus US-PA & 3.552 & $0.0099^{*}$ \\
CF-PA versus TP-PA & 0.995 & 0.75362 \\
TP-PA versus US-PA & -2.556 & 0.08118 \\
\hline
\end{tabular}

The NMDS analysis ordered sites by habitat type, separating tree plantations and urban settlements from the other habitat types, indicating that similarity in species trait assemblages in tree plantations and urban settlements was different from that of crop fields, cattle pastures, and protected areas. Each habitat type was characterized by the occurrence of traits related to habitat characteristics: for example, generalist traits in urban areas, foraging and nesting in trees and shrubs in tree plantations, and nesting on grasses or ground in protected areas, cattle pastures, and crop fields (Figs. A2.1 to A2.4 in Appendix 2). Bird species with a specific diet, e.g., frugivore, carnivore, and invertebrate diet, were more frequent in protected areas, cattle pastures, and some crop fields. In addition, protected areas, cattle pastures, and some crop fields were characterized by the occurrence of species that forage in the air or water, show some migratory status, and nest in trees and shrubs (Figs. A2.1, A2.2, and A2.4 in Appendix
2), and species with wetlands as primary habitats (Fig. A2.3 in Appendix 2).

Fig. 5. Averages of species composition similarity values ( 1 - Jaccard) between each habitat type and protected areas of the Pampean grasslands. Vertical lines show standard deviations. Different letters indicate significant differences $(P<0.05)$ between pairs of habitat types: results of multiple comparisons of means (Tukey contrasts) of 1 minus Jaccard between habitat types.

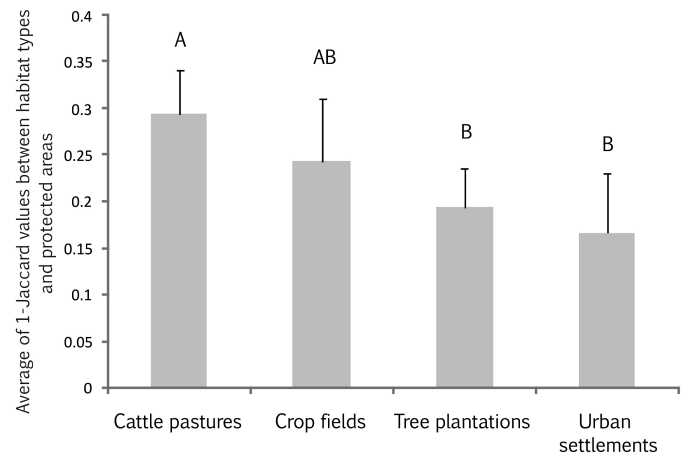

Fig. 6. Averages of functional similarity values (FSor) between each habitat type and protected areas of the Pampean grasslands. Vertical lines show standard deviations. Different letters indicate significant differences $(P<0.05)$ between pairs of habitat types: results of multiple comparisons of means (Tukey contrasts) of FSor between habitat types.

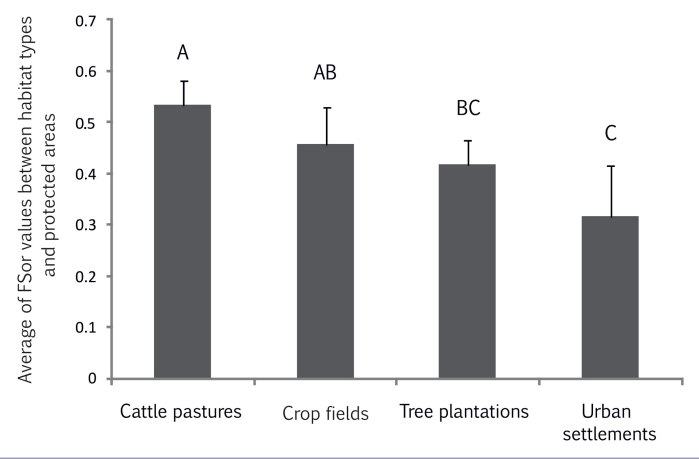

Results of the SIMPER analysis highlighted the primary traits contributing the most to differentiate land uses (Fig. 7). In urban settlements, common traits included those covering wide ranges or related to impervious areas, such as cosmopolitan distribution, urban areas as primary habitat, parasitic breeding such as laying eggs in the active nests of other species, and nesting in inactive nests of other species. In contrast, in cattle pastures, crop fields, and protected areas, the most frequent species traits were related to narrow ranges and high vulnerability to extinction, such as medium sensitivity, i.e., species is not in short-term danger but is vulnerable if habitat destruction continues; migratory status; 
Fig. 7. Nonmetric multidimensional scaling (NMDS) analysis of habitat type sites and protected areas based on the similarity of traits. The function adds traits scores to the site ordination. Only 23 traits resulting from SIMPER (similarity percentage) are shown. Acronyms of categorical traits are given in Appendix 1.

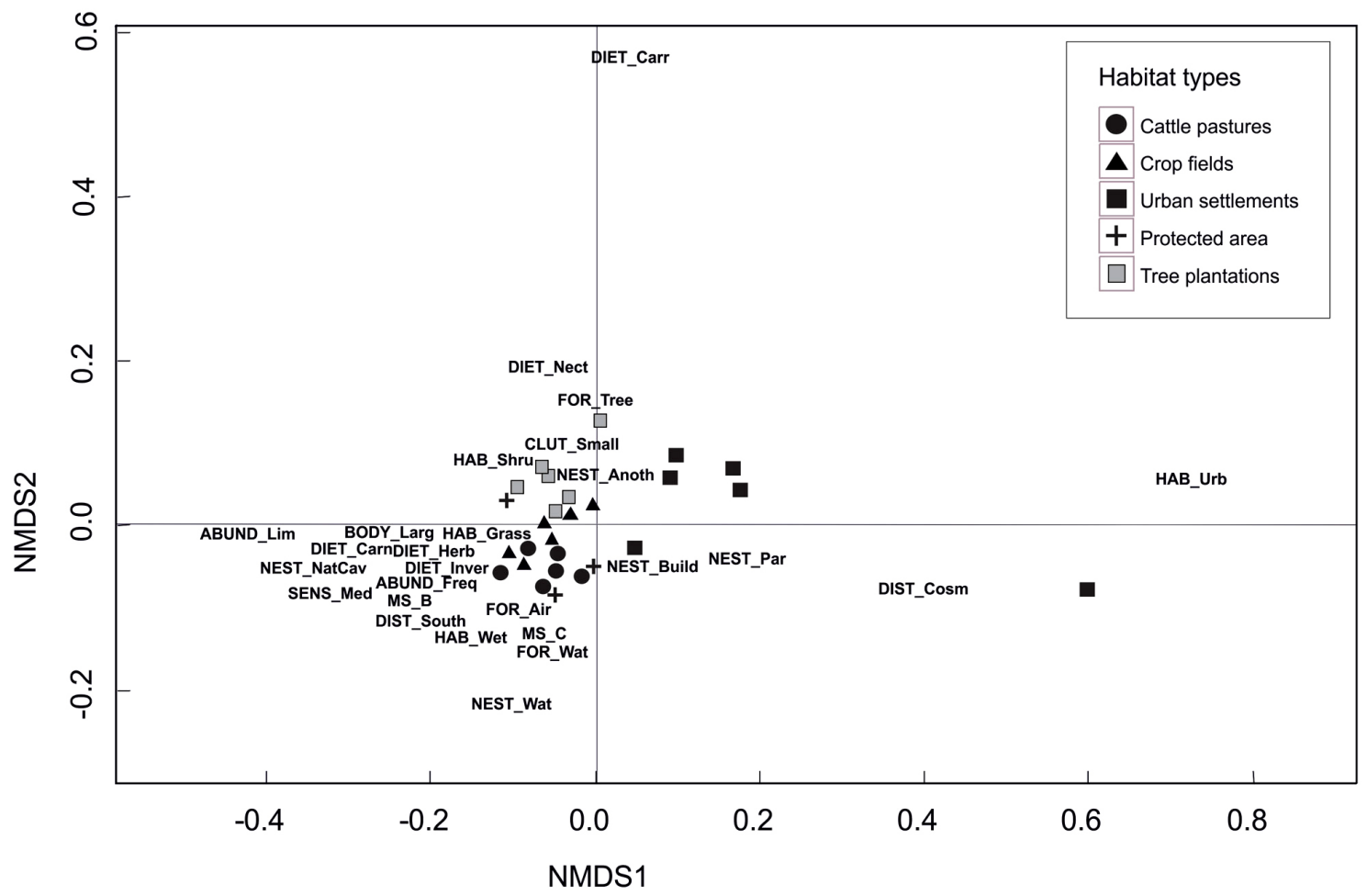

foraging in the air and water; nesting in vegetation on water; herbivorous and carnivorous diet; and large body size.

\section{DISCUSSION}

We are the first to simultaneously compare bird taxonomic and functional diversities between the natural habitat and the different types of anthropogenic habitats in a grassland biome, providing new insights into grassland bird communities in general and into the Pampean region of South America in particular. The observed species richness, species composition similarity, functional trait diversity, and functional similarity of bird assemblages in cattle pastures were the closest to those observed in protected grasslands, followed by crop fields, tree plantations, and urban settlements. Although previous studies have emphasized the relevance of cattle pastures, as opposed to other anthropogenic habitat types, for the conservation of grassland bird species in North America (Askins et al. 2007), South America (Azpiroz et al. 2012), and the Pampean region (Codesido and Bilenca 2011), our work extends the relevance to the conservation of bird functional traits. Therefore, we emphasize the need to protect the native habitat, because none of the studied anthropogenic habitat types is able to support all the diversity of native grasslands.

Our results show that livestock is better than other land uses to preserve more grassland birds and their traits. Low to moderate rates of cattle grazing ( 0.4 to 0.7 animals $/$ ha) may promote vegetation growth, favoring the diversity and abundance of invertebrates and seeds, thus providing food supply for invertebrate- and seed-eating birds (Gibson et al. 1992, Perkins et al. 2000, Fontana et al. 2016). Also, moderate grazing rates may provide grass coverage and height similar to those of natural grasslands, as found in the rangelands of North America (Peterjohn 2003). Furthermore, pastures may offer horizontal and vertical structural diversity for birds nesting on the ground, such as the Burrowing Owl (Athene cunicularia; Pairo et al. 2017), or on grasses, such as the Great Pampa-Finch (Embernagra platensis), the Brown-and-yellow Marshbird (Pseudoleistes virescens), the Hudson's Canastero (Asthenes hudsoni), and the Greater Rhea (Rhea americana; Codesido et al. 2013). Also, grazing management could be used in the restoration of seminatural grasslands (WallisDeVries et al. 1998). Grazing has been considered the most practical option to reverse the decline of northern European grasslands (Pykälä 2003), and cattle have been considered as ecosystem engineers for the conservation of semiarid rangelands of the western North American Great Plains (Derner et al. 2009). Based on our results and other studies, it is recommended in land use planning for bird conservation to prioritize cattle grazing over other land uses in the Pampean grasslands and, presumably, in other grasslands of the world as well.

Although many studies have documented a decline in the abundance and number of grassland bird species because of agriculture (Peterjohn and Sauer 1999, Donald et al. 2001, Canavelli et al. 2004, Azpiroz et al. 2012), we found that bird communities in crop fields showed relatively high taxonomic and 
functional similarities relative to protected grasslands. Our work was designed at the scale of land use (agriculture), pooling the most abundant crop fields of the study area. For example, soybeans, corn, and wheat were included in agricultural sites to represent agricultural use rather than restricting the findings to only one type of crop. However, agricultural practices and the structure of crop fields may have different effects on birds. Some fields with high and dense crop cover may serve as refuges from predators and extreme weather conditions and provide abundant food resources (Wilson et al. 2005); for example, large flocks of the White-browed Meadowlark (Sturnella superciliaris), a grassland species, usually forage in croplands (Belton 1994). During our spring surveys, crops were primarily soybean, a summer crop with low height during our surveys, and mature wheat, a winter crop harvested in late spring to early summer, and about $1 \mathrm{~m}$ in height during our surveys, which may offer a tall herbaceous vegetation stratum. Therefore, mature wheat fields could have contributed to the relatively high environmental similarity between crop fields and protected areas. Weyland et al. (2014) also found a large group of grassland birds, e.g., the Spotted Nothura (Nothura maculosa), the White-browed Meadowlark, and so on, positively associated with wheat coverage; it is possible that wheat crop fields offer some environmental conditions, such as tall vegetation and low soil compaction, that may be more consistent than cattle pastures with the ecological niches of grassland birds. Also, habitat structure showed higher seasonality in agricultural lands than in cattle grazing sites. In agricultural lands, there are periods over the year, after harvesting and before seeding, with low vegetation coverage. In the Pampean region, the traditional rotation management between crops and cattle pastures has been replaced mainly by the rotation between different crops, i.e., soybean, wheat, and maize, and, further, soybean monoculture system. Agricultural intensification and expansion to soybean monocultures were induced by the use of the direct sawing technique, transgenic seeds, and agrochemicals such as insecticides, herbicides, fungicides, and fertilizers (Baldi and Paruelo 2008). Previous studies revealed that intense agriculture was more detrimental to the avian community than pastoral farming in the Pampean region (Verhulst et al. 2004, Filloy and Bellocq 2007).

Tree plantations differed from natural grasslands in vegetation structure, species composition, and functional diversity. Many studies have documented that tree plantations developed in natural grasslands alter water and soil (Jobbágy and Jackson 2004, Silveira and Alonso 2009) and affect biodiversity (Brockerhoff et al. 2008, Buscardo et al. 2008). Nonnative tree plantations have replaced cattle raising in some grasslands of southeastern South America (Overbeck et al. 2007, Baldi and Paruelo 2008), resulting in negative effects on several threatened grassland birds (Di Giacomo and Krapovickas 2001, Azpiroz et al. 2012, Fontana et al. 2016). The replacement of grasslands with tree plantations may result in the local loss of some species traits related to grasslands as primary habitat and to some ecosystem functions. Consequently, our results provide evidence against the promotion of forestry in the Pampean grasslands.

Urbanization imposes a powerful environmental filter to native grasslands, changing deeply the original environmental conditions and disrupting the natural vegetation dynamics (Williams et al. 2005). Our results showed that urban settlements were the most different habitat type relative to natural habitats regarding vegetation structure, species composition, and functional diversity. Furthermore, this habitat type held the lowest species richness and functional diversity among other land uses in the Pampean grasslands. Low species richness and functional diversity in urban areas have been previously documented for birds (Ortega-Álvarez and MacGregor-Fors 2009, Pauw and Louw 2012, Leveau et al. 2015). High levels of urbanization reduce bird species richness (Chace and Walsh 2006, Faeth et al. 2011) and functional diversity because environmental filters allow only the persistence of species with traits to tolerate urban constraints (Petchey and Gaston 2007, Croci et al. 2008).

Understanding the relationship between species traits and environmental characteristics is essential to predict community responses to land use and allows us to make suitable conservation decisions (Hausner et al. 2003). Our site ordination based on the similarity of the functional trait assemblages was consistent with habitat type characteristics; in general, each habitat type was characterized by a set of species with traits related to vegetation structure. However, we also found some traits related to the heterogeneity of habitat types, for example, "nesting in trees" in protected areas. Grasslands in protected areas may have a few isolated trees, shrubs, or small woodlots of Celtis tala (Cabrera 1976). Furthermore, in cattle pastures we found bird assemblages with some traits related to aquatic habits, such as foraging in water, nesting in vegetation on water, and having wetlands as primary habitat, in sites located in the southern Pampean region, i.e., the Flooding Pampa, characterized by very slight slopes and poor water drainage resulting in water accumulation during periods of abundant rainfall (Miñarro and Bilenca 2008). Our results indicate that keeping isolated woodlots in cattle pastures and farmland, which offer opportunities for birds holding tree-related traits, and temporary ponds in cattle pastures, which could support greater abundance of wetland birds that forage in these zones as well as in grasslands (Canevari et al. 1991, Codesido et al. 2012), will enhance the conservation of bird functional diversity.

As expected, in urban settlements we found bird assemblages composed of species characterized by generalist traits because these species can tolerate urban constraints. In city parks of France, Lizée et al. (2011) also found bird assemblages with omnivorous species that nest on buildings and have high egg production. Croci et al. (2008) found that the presence of sedentary and widely distributed bird species was related to urban areas in Switzerland and France, and Silva et al. (2016) found higher abundance of habitat generalist birds in urban than in periurban areas of southern Chile. The environmental filters imposed by urbanization prevent the establishment of many native species, i.e., urban avoiders, holding specific traits such as long-term migrants, diet specialists, e.g., exclusively feeding on arthropods, or traits that indicate high sensitivity to human disturbances, e.g., nesting on the ground (Seress and Liker 2015).

Many studies have proposed that the presence of certain traits based on foraging substrate, diet, and nest-site preferences in the local assemblage may be used as indicators of habitat alteration (Hausner et al. 2003, Schulze et al. 2004, Vandewalle et al. 2010). For land uses in the Pampas, in addition to the presence of species with traits related to vegetation structure, other traits that 
contributed the most to differentiate habitat types, highlighted by the SIMPER analysis, may be good indicators of environmental change. Our results showed that land uses that preserve bird functional diversity of natural grasslands, at least partially, will support species holding traits related to narrow ranges and high or medium vulnerability to extinction rather than traits covering wide amplitudes or indicating low vulnerability. Only $1 \%$ of the original grassland is conserved in public protected areas in the region, and many threatened grassland birds are found on private lands (Azpiroz et al. 2012). Grassland conservation helps not only to preserve functional traits but also to protect species that are at conservation risk, because the native habitat has many species that were not found in the studied anthropogenic habitat types.

\section{CONCLUSION}

We used multiple facets of diversity to understand community responses to environmental changes caused by human activities developing in one of the terrestrial biomes at the greatest conservation risk. We found that cattle pastures and urban settlements had the lowest and highest negative effect, respectively, on the species community and functional trait assemblage of native birds in the Pampean grasslands. We predict that the land use ranking of increasing negative impact of human activities in the Pampean grasslands of Argentina, i.e., cattle pastures, crop fields, tree plantations, and urban settlements, will remain true for other temperate grasslands. We hypothesize, however, that such ranking will change when the same human activities develop in forest biomes, because environmental similarity between anthropogenic habitat types and the natural habitat will also change (Filloy et al. 2010, Corbelli et al. 2015, Santoandré 2017).

Responses to this article can be read online at: http://www.ace-eco.org/issues/responses.php/1293

\begin{abstract}
Acknowledgments:
We thank S. Santoandré, C. S. Ramos, L. Leveau, E. de León, P. E. Pairo, and G. Nicosia for their assistance in field and laboratory work. Logistical support and legal permissions were provided by Administración Parques Nacionales (PN El Palmar and PN Campos del Tuyú) of Argentina. We thank L. R. Antoniazzi and Fundación Federico Wildermuth, Forestal Argentina, Paul Forestal S.R.L., La Constancia, and R. Forclaz that allowed us to work in their properties and provided logistical support. The subject editor and two anonymous reviewers made valuable suggestions that improved the manuscript. The research was funded by the Agencia Nacional de Promoción Cientifica y Tecnológica of Argentina, the Universidad de Buenos Aires, and the Consejo Nacional de Investigaciones Cientificas y Técnicas (Argentina).
\end{abstract}

\section{LITERATURE CITED}

Allen, A. P., and R. J. O'Connor. 2000. Interactive effects of land use and other factors on regional bird distributions. Journal of Biogeography 27:889-900. http://dx.doi.org/10.1046/

j.1365-2699.2000.00453.x
Anderson, M. J., K. E. Ellingsen, and B. H. McArdle. 2006. Multivariate dispersion as a measure of beta diversity. Ecology Letters 9:683-693. http://dx.doi.org/10.1111/j.1461-0248.2006.00926. $\mathrm{x}$

Askins, R. A., F. Chávez-Ramírez, B. C. Dale, C. A. Haas, J. R. Herkert, F. L. Knopf, and P. D. Vickery. 2007. Conservation of grassland birds in North America: understanding ecological processes in different regions. Ornithological Monographs 64:1-46. http://dx.doi.org/10.2307/40166905

Azpiroz, A. B., J. P. Isacch, R. A. Dias, A. S. Di Giacomo, C. S. Fontana, and C. M. Palarea. 2012. Ecology and conservation of grassland birds in southeastern South America: a review. Journal of Field Ornithology 83:217-246. http://dx.doi.org/10.1111/ j.1557-9263.2012.00372.x

Baldi, G., and J. M. Paruelo. 2008. Land-use and land cover dynamics in South American temperate grasslands. Ecology and Society 13(2):6. http://dx.doi.org/10.5751/ES-02481-130206

Baselga, A., and C. D. L. Orme. 2012. betapart: an R package for the study of beta diversity. Methods in Ecology and Evolution 3:808-812. http://dx.doi.org/10.1111/j.2041-210X.2012.00224.x

Belton, W. 1994. Aves do Rio Grande do Sul: distribuição e biologia. Editora Unisinos, São Leopoldo, Rio Grande do Sul, Brazil.

Bennett, A. F., S. A. Hinsley, P. E. Bellamy, R. D. Swetnam, and R. Mac Nally. 2004. Do regional gradients in land-use influence richness, composition and turnover of bird assemblages in small woods? Biological Conservation 119:191-206. http://dx.doi. org/10.1016/j.biocon.2003.11.003

Benton, T. G., J. A. Vickery, and J. D. Wilson. 2003. Farmland biodiversity: is habitat heterogeneity the key? Trends in Ecology \& Evolution 18:182-188. http://dx.doi.org/10.1016/S0169-5347 (03)00011-9

Bibby, C., M. Jones, and S. Marsden. 1998. Expedition field techniques: bird surveys. Expedition Advisory Centre, Royal Geographical Society, London, UK.

Bilenca, D., and F. Miñarro. 2004. Identificación de Áreas Valiosas de Pastizal (AVPs) en las Pampas y Campos de Argentina, Uruguay y sur de Brasil. Fundación Vida Silvestre Argentina, Buenos Aires, Argentina.

BirdLife International. 2018. Data zone. BirdLife International, Cambridge, UK. [online] URL: http://datazone.birdlife.org/

Bregman, T. P., A. C. Lees, H. E. A. MacGregor, B. Darski, N. G. de Moura, A. Aleixo, J. Barlow, and J. A. Tobias. 2016. Using avian functional traits to assess the impact of land-cover change on ecosystem processes linked to resilience in tropical forests. Proceedings of the Royal Society B: Biological Sciences 283:20161289. http://dx.doi.org/10.1098/rspb.2016.1289

Brizuela, A. B., S. Milera, and J. Mestres. 2003. Plantaciones de Eucaliptos y Pinos en los departamentos del este de Entre Rios. Pages 73-79 in XVIII Jornadas Forestales de Entre Ríos, Concordia. INTA, Concordia, Entre Ríos, Argentina.

Brockerhoff, E. G., H. Jactel, J. A. Parrotta, C. P. Quine, and J. Sayer. 2008. Plantation forests and biodiversity: oxymoron or 
opportunity? Biodiversity and Conservation 17:925-951. http://dx. doi.org/10.1007/s10531-008-9380-x

Buscardo, E., G. F. Smith, D. L. Kelly, H. Freitas, S. Iremonger, F. J. G. Mitchell, S. O'Donoghue, and A.-M. McKee. 2008. The early effects of afforestation on biodiversity of grasslands in Ireland. Biodiversity and Conservation 17:1057-1072. http://dx. doi.org/10.1007/s10531-007-9275-2

Cabrera, A. L. 1976. Enciclopedia Argentina de agricultura y jardinería: regiones fitogeográficas Argentinas. Acme, Buenos Aires, Argentina.

Cadotte, M. W., K. Carscadden, and N. Mirotchnick. 2011. Beyond species: functional diversity and the maintenance of ecological processes and services. Journal of Applied Ecology 48:1079-1087. http://dx.doi.org/10.1111/j.1365-2664.2011.02048. $\mathrm{x}$

Canavelli, S., M. E. Zaccagnini, J. Torresin, N. Calamari, P. Ducommun, and P. Capllonch. 2004. Monitoreo Extensivo de Aves en el Centro-Sur de Entre Ríos. Insugeo 12:349-362.

Canevari, M., P. Canevari, G. Carrizo, G. Harris, J. Rodriguez Mata, and R. Straneck. 1991. Nueva guía de las aves argentinas. Fundación Acindar, Buenos Aires, Argentina.

Cardinale, B. J., J. E. Duffy, A. Gonzalez, D. U. Hooper, C. Perrings, P. Venail, A. Narwani, G. M. Mace, D. Tilman, D. A. Wardle, A. P. Kinzig, G. C. Daily, M. Loreau, J. B. Grace, A. Larigauderie, D. S. Srivastava, and S. Naeem. 2012. Biodiversity loss and its impact on humanity. Nature 486:59-67. http://dx.doi. org/10.1038/nature11148

Catterall, C. P., J. A. Cousin, S. Piper, and G. Johnson. 2010. Longterm dynamics of bird diversity in forest and suburb: decay, turnover or homogenization? Diversity and Distributions 16:559-570. http://dx.doi.org/10.1111/j.1472-4642.2010.00665.x

Ceballos, G., A. Davidson, R. List, J. Pacheco, P. ManzanoFischer, G. Santos-Barrera, and J. Cruzado. 2010. Rapid decline of a grassland system and its ecological and conservation implications. PLOS ONE 5:e8562. http://dx.doi.org/10.1371/ journal.pone.0008562

Chace, J. F., and J. J. Walsh. 2006. Urban effects on native avifauna: a review. Landscape and Urban Planning 74:46-69. http://dx.doi.org/10.1016/j.landurbplan.2004.08.007

Chamberlain, D. E., and R. J. Fuller. 2000. Local extinctions and changes in species richness of lowland farmland birds in England and Wales in relation to recent changes in agricultural land-use. Agriculture, Ecosystems \& Environment 78:1-17. http://dx.doi. org/10.1016/S0167-8809(99)00105-X

Clarke, K. R. 1993. Non-parametric multivariate analyses of changes in community structure. Australian Journal of Ecology 18:117-143. http://dx.doi.org/10.1111/j.1442-9993.1993.tb00438. $\mathrm{x}$

Codesido, M., and D. N. Bilenca. 2011. Los pastizales y el servicio de soporte de la biodiversidad: Respuesta de la riqueza de aves terrestres a los usos de la tierra en la provincia de Buenos Aires. Pages 511-526 in P. Laterra, E. G. Jobbágy, and J. M. Paruelo, editors. Valoración de servicios ecosistémicos: Conceptos, herramientas y aplicaciones para el ordenamiento territorial. Ediciones INTA, Buenos Aires, Argentina.

Codesido, M., C. González-Fischer, and D. Bilenca. 2012. Agricultural land-use, avian nesting and rarity in the Pampas of central Argentina. Emu 112:46-54. http://dx.doi.org/10.1071/ MU11049

Codesido, M., C. M. González-Fischer, and D. N. Bilenca. 2013. Landbird assemblages in different agricultural landscapes: a case study in the Pampas of central Argentina. Condor 115:8-16. http:// dx.doi.org/10.1525/cond.2012.120011

Cody, M. L. 1985. Habitat selection in birds. Academic Press, Orlando, Florida, USA.

Cofre, H. L., K. Böhning-Gaese, and P. A. Marquet. 2007. Rarity in Chilean forest birds: which ecological and life-history traits matter? Diversity and Distributions 13:203-212. http://dx.doi. org/10.1111/j.1472-4642.2006.00312.x

Corbelli, J. M., G. A. Zurita, J. Filloy, J. P. Galvis, N. I. Vespa, and I. Bellocq. 2015. Integrating taxonomic, functional and phylogenetic beta diversities: interactive effects with the biome and land use across taxa. PLoS ONE 10:e0126854. http://dx.doi. org/10.1371/journal.pone.0126854

Cornwell, W. K., and D. D. Ackerly. 2009. Community assembly and shifts in plant trait distributions across an environmental gradient in coastal California. Ecological Monographs 79:109-126. http://dx.doi.org/10.1890/07-1134.1

Croci, S., A. Butet, and P. Clergeau. 2008. Does urbanization filter birds on the basis of their biological traits? Condor 110:223-240. http://dx.doi.org/10.1525/cond.2008.8409

Davidson, A. D., J. K. Detling, and J. H. Brown. 2012. Ecological roles and conservation challenges of social, burrowing, herbivorous mammals in the world's grasslands. Frontiers in Ecology and the Environment 10:477-486. http://dx.doi. org/10.1890/110054

DeGraaf, R. M., A. D. Geis, and P. A. Healy. 1991. Bird population and habitat surveys in urban areas. Landscape and Urban Planning 21:181-188. http://dx.doi.org/10.1016/0169-2046 (91)90017-G

De la Peña, M. R. 2013. Nidos y reproducción de las Aves Argentinas. Ediciones Biológica. Serie Naturaleza, Conservación y Sociedad No. 8. Museo Provincial de Ciencias Naturales "Florentino Ameghino," Santa Fe, Argentina.

De la Peña, M. R. 2016. Aves Argentinas: descripcón, comportamiento, reproducción y distribución. Comunicaciones del Museo Provincial de Ciencias Naturales "Florentino Ameghino" (Nueva Serie) 19(1):1-459.

Del Hoyo, J., A. Elliott, J. Sargatal, D. A. Christie, and E. de Juana. 2016. Handbook of the birds of the world alive. Lynx Edici, Barcelona, Spain.

Derner, J. D., W. K. Lauenroth, P. Stapp, and D. J. Augustine. 2009. Livestock as ecosystem engineers for grassland bird habitat in the western Great Plains of North America. Rangeland Ecology \& Management 62:111-118. http://dx.doi.org/10.2111/08-008.1 
Di Giacomo, A., and S. Krapovickas. 2001. Afforestation threatens Argentina's grasslands. World Birdwatch 23(3):24-25.

Diniz-Filho, J. A. F., M. V. Cianciaruso, T. F. Rangel, and L. M. Bini. 2011. Eigenvector estimation of phylogenetic and functional diversity. Functional Ecology 25:735-744. http://dx.doi.org/10.1111/ j.1365-2435.2011.01836.x

Donald, P. F., R. E. Gree, and M. F. Heath. 2001. Agricultural intensification and the collapse of Europe's farmland bird populations. Proceedings of the Royal Society B: Biological Sciences 268:25-29. http://dx.doi.org/10.1098/rspb.2000.1325

Donald, P. F., F. J. Sanderson, I. J. Burfield, and F. P. J. van Bommel. 2006. Further evidence of continent-wide impacts of agricultural intensification on European farmland birds, 19902000. Agriculture, Ecosystems \& Environment 116:189-196. http:// dx.doi.org/10.1016/j.agee.2006.02.007

Facelli, J. M., R. J. C. Leon, and V. A. Deregibus. 1989. Community structure in grazed and ungrazed grassland sites in the Flooding Pampa, Argentina. American Midland Naturalist 121:125-133. http://dx.doi.org/10.2307/2425663

Faeth, S. H., C. Bang, and S. Saari. 2011. Urban biodiversity: patterns and mechanisms. Annals of the New York Academy of Sciences 1223:69-81. http://dx.doi.org/10.1111/j.1749-6632.2010.05925. $\mathrm{x}$

Feeley, K. J., T. W. Gillespie, D. J. Lebbin, and H. S. Walter. 2007. Species characteristics associated with extinction vulnerability and nestedness rankings of birds in tropical forest fragments. Animal Conservation 10:493-501. http://dx.doi.org/10.1111/ j.1469-1795.2007.00140.x

Filloy, J., and M. I. Bellocq. 2007. Patterns of bird abundance along the agricultural gradient of the Pampean region. Agriculture, Ecosystems \& Environment 120:291-298. http://dx. doi.org/10.1016/j.agee.2006.09.013

Filloy, J., S. Grosso, and M. I. Bellocq. 2015. Urbanization altered latitudinal patterns of bird diversity-environment relationships in the southern Neotropics. Urban Ecosystems 18:777-791. http:// dx.doi.org/10.1007/s11252-014-0429-1

Filloy, J., G. A. Zurita, J. M. Corbelli, and M. I. Bellocq. 2010. On the similarity among bird communities: testing the influence of distance and land use. Acta Oecologica 36:333-338. http://dx. doi.org/10.1016/j.actao.2010.02.007

Flynn, D. F. B., M. Gogol-Prokurat, T. Nogeire, N. Molinari, B. T. Richers, B. B. Lin, N. Simpson, M. M. Mayfield, and F. DeClerck. 2009. Loss of functional diversity under land use intensification across multiple taxa. Ecology Letters 12:22-33. http://dx.doi.org/10.1111/j.1461-0248.2008.01255.x

Foley, J. A., R. DeFries, G. P. Asner, C. Barford, G. Bonan, S. R. Carpenter, F. S. Chapin, M. T. Coe, G. C. Daily, H. K. Gibbs, J. H. Helkowski, T. Holloway, E. A. Howard, C. J. Kucharik, C. Monfreda, J. A. Patz, I. C. Prentice, N. Ramankutty, and P. K. Snyder. 2005. Global consequences of land use. Science 309:570-574. http://dx.doi.org/10.1126/science.1111772

Fontana, C. S., G. Dotta, C. K. Marques, M. Repenning, C. E. Agne, and R. J. dos Santos. 2016. Conservation of grassland birds in South Brazil: a land management perspective. Natureza \& Conservação 14:83-87. http://dx.doi.org/10.1016/j.ncon.2016.09.005
Galindo Leal, C., and I. de Gusmão Câmara. 2003. The Atlantic Forest of South America: biodiversity status, threats, and outlook. Island, Washington, D.C., USA.

Garaffa, P. I., J. Filloy, and M. I. Bellocq. 2009. Bird community responses along urban-rural gradients: does the size of the urbanized area matter? Landscape and Urban Planning 90:33-41. http://dx.doi.org/10.1016/j.landurbplan.2008.10.004

Gascon, C., T. E. Lovejoy, R. O. Bierregaard, Jr., J. R. Malcolm, P. C. Stouffer, H. L. Vasconcelos, W. F. Laurance, B. Zimmerman, M. Tocher, and S. Borges. 1999. Matrix habitat and species richness in tropical forest remnants. Biological Conservation 91:223-229. http://dx.doi.org/10.1016/S0006-3207(99)00080-4

Gibson, C. W. D., C. Hambler, and V. K. Brown. 1992. Changes in spider (Araneae) assemblages in relation to succession and grazing management. Journal of Applied Ecology 29:132-142. http://dx.doi.org/10.2307/2404356

Goriup, P. D. 1988. Ecology and conservation of grassland birds. International Council for Bird Preservation, Cambridge, UK.

Hall, A. J., C. M. Rebella, C. M. Ghersa, and J. P. Culot. 1992. Field crop systems of the Pampas. Pages 413-450 in C. J. Pearson, editor. Field crop ecosystems. Ecosystems of the World 18. Elsevier, Amsterdam, The Netherlands.

Hausner, V. H., N. G. Yoccoz, and R. A. Ims. 2003. Selecting indicator traits for monitoring land use impacts: birds in northern coastal birch forests. Ecological Applications 13:999-1012. http:// dx.doi.org/10.1890/1051-0761(2003)13[999:SITFML]2.0.CO;2

Henwood, W. D. 2010. Toward a strategy for the conservation and protection of the world's temperate grasslands. Great Plains Research 20:121-134.

Hobbs, R. J., S. Arico, J. Aronson, J. S. Baron, P. Bridgewater, V. A. Cramer, P. R. Epstein, J. J. Ewel, C. A. Klink, A. E. Lugo, D. Norton, D. Ojima, D. M. Richardson, E. W. Sanderson, F. Valladares, M. Vilà, R. Zamora, and M. Zobel. 2006. Novel ecosystems: theoretical and management aspects of the new ecological world order. Global Ecology and Biogeography 15:1-7. http://dx.doi.org/10.1111/j.1466-822X.2006.00212.x

Hoekstra, J. M., T. M. Boucher, T. H. Ricketts, and C. Roberts. 2005. Confronting a biome crisis: global disparities of habitat loss and protection. Ecology Letters 8:23-29. http://dx.doi. org/10.1111/j.1461-0248.2004.00686.x

Holmes, R. T., R. E. Bonney, Jr., and S. W. Pacala. 1979. Guild structure of the Hubbard Brook bird community: a multivariate approach. Ecology 60:512-520. http://dx.doi.org/10.2307/1936071

Jaksić, F. M., and R. G. Medel. 1990. Objective recognition of guilds: testing for statistically significant species clusters. Oecologia 82:87-92. http://dx.doi.org/10.1007/BF00318537

Jobbágy, E. G., and R. B. Jackson. 2004. Groundwater use and salinization with grassland afforestration. Global Change Biology 10:1299-1312. http://dx.doi.org/10.1111/j.1365-2486.2004.00806. $\mathrm{x}$

Kembel, S. W., P. D. Cowan, M. R. Helmus, W. K. Cornwell, H. Morlon, D. D. Ackerly, S. P. Blomberg, and C. O. Webb. 2010. Picante: R tools for integrating phylogenies and ecology. Bioinformatics 26:1463-1464. http://dx.doi.org/10.1093/bioinformatics/ btq166 
Kindt, R., and R. Coe. 2005. Tree diversity analysis: a manual and software for common statistical methods for ecological and biodiversity studies. World Agroforestry Centre, Nairobi, Kenya.

Kraft, N. J. B., P. B. Adler, O. Godoy, E. C. James, S. Fuller, and J. M. Levine. 2015. Community assembly, coexistence and the environmental filtering metaphor. Functional Ecology 29:592-599. http://dx.doi.org/10.1111/1365-2435.12345

Laliberté, E., and P. Legendre. 2010. A distance-based framework for measuring functional diversity from multiple traits. Ecology 91:299-305. http://dx.doi.org/10.1890/08-2244.1

Landi, M., M. Oesterheld, and V. A. Deregibus. 1987. Manual de especies forrajeras de los pastizales naturales de Entre Ríos. AACREA, Buenos Aires, Argentina.

Legendre, P., and L. Legendre. 1998. Numerical ecology. Developments in Environmental Modelling, Volume 20. Elsevier, Amsterdam, The Netherlands.

Legendre, P., and L. Legendre. 2012. Numerical ecology. Developments in Environmental Modelling, Volume 24. Elsevier, Amsterdam, The Netherlands.

León, R. J. C., G. M. Rusch, and M. Oesterheld. 1984. Pastizales pampeanos - impacto agropecuario. Phytocoenologia 12:201-218. http://dx.doi.org/10.1127/phyto/12/1984/201

Leveau, L. M. 2013. Bird traits in urban-rural gradients: how many functional groups are there? Journal of Ornithology 154:655-662. http://dx.doi.org/10.1007/s10336-012-0928-x

Leveau, L. M., F. I. Isla, and M. I. Bellocq. 2015. Urbanization and the temporal homogenization of bird communities: a case study in central Argentina. Urban Ecosystems 18:1461-1476. http://dx.doi.org/10.1007/s11252-015-0469-1

Lizée, M.-H., J.-F. Mauffrey, T. Tatoni, and M. DeschampsCottin. 2011. Monitoring urban environments on the basis of biological traits. Ecological Indicators 11:353-361. http://dx.doi. org/10.1016/j.ecolind.2010.06.003

López-Lanús, B., P. Grilli, A. S. Di Giacomo, E. E. Coconier, and R. Banchs. 2008. Categorización de las aves de la Argentina según suestado de conservación. Informe de Aves Argentinas/Asociación Ornitológica del Plata y Secretaría de Ambiente y Desarrollo Sustentable, Buenos Aires, Argentina.

Luck, G. W., A. Carter, and L. Smallbone. 2013. Changes in bird functional diversity across multiple land uses: interpretations of functional redundancy depend on functional group identity. PLoS ONE 8:e63671. http://dx.doi.org/10.1371/journal.pone.0063671

MacArthur, R. H., and J. W. MacArthur. 1961. On bird species diversity. Ecology 42:594-598. http://dx.doi.org/10.2307/1932254

Magurran, A. E. 2004. Measuring biological diversity. Blackwell, Oxford, UK.

Mayfield, M. M., D. Ackerly, and G. C. Daily. 2006. The diversity and conservation of plant reproductive and dispersal functional traits in human-dominated tropical landscapes. Journal of Ecology 94:522-536. http://dx.doi.org/10.1111/j.1365-2745.2006.01108. $\mathrm{x}$

Mayfield, M. M., S. P. Bonser, J. W. Morgan, I. Aubin, S. McNamara, and P. A. Vesk. 2010. What does species richness tell us about functional trait diversity? Predictions and evidence for responses of species and functional trait diversity to land-use change. Global Ecology and Biogeography 19:423-431. http://dx. doi.org/10.1111/j.1466-8238.2010.00532.x

McGill, B. J., B. J. Enquist, E. Weiher, and M. Westoby. 2006. Rebuilding community ecology from functional traits. Trends in Ecology \& Evolution 21:178-185. http://dx.doi.org/10.1016/j. tree.2006.02.002

McMaster, D. G., and S. K. Davis. 2001. An evaluation of Canada's Permanent Cover Program: habitat for grassland birds? Journal of Field Ornithology 72:195-210. http://dx.doi. org/10.1648/0273-8570-72.2.195

Millennium Ecosystem Assessment. 2005. Ecosystems and human well-being: biodiversity synthesis. World Resources Institute, Washington, D.C., USA.

Miñarro, F., and D. Bilenca. 2008. The conservation status of temperate grasslands in central Argentina. Fundación Vida Silvestre Argentina, Buenos Aires, Argentina

Mouillot, D., N. A. J. Graham, S. Villéger, N. W. H. Mason, and D. R. Bellwood. 2013. A functional approach reveals community responses to disturbances. Trends in Ecology \& Evolution 28:167-177. http://dx.doi.org/10.1016/j.tree.2012.10.004

Mueller-Dombois, D., and H. Ellenberg. 1974. Aims and methods of vegetation ecology. Wiley, New York, New York, USA.

Naeem, S., J. E. Duffy, and E. Zavaleta. 2012. The functions of biological diversity in an age of extinction. Science 336:1401-1406. http://dx.doi.org/10.1126/science.1215855

Naeem, S., and J. P. Wright. 2003. Disentangling biodiversity effects on ecosystem functioning: deriving solutions to a seemingly insurmountable problem. Ecology Letters 6:567-579. http://dx.doi.org/10.1046/j.1461-0248.2003.00471.x

Narosky, S., D. Yzurieta, and H. Matarasso. 2010. Aves de Argentina y Uruguay: guía de identificación [Birds of Argentina \& Uruguay: a field guide]. Vazquez Mazzini, Buenos Aires, Argentina.

Norberg, J., D. P. Swaney, J. Dushoff, J. Lin, R. Casagrandi, and S. A. Levin. 2001. Phenotypic diversity and ecosystem functioning in changing environments: a theoretical framework. Proceedings of the National Academy of Sciences of the United States of America 98:11376-11381. http://dx.doi.org/10.1073/pnas.171315998

Oksanen, J., F. G. Blanchet, R. Kindt, P. Legendre, P. R. Minchin, R. B. O'Hara, G. L. Simpson, P. Solymos, M. H. H. Stevens, and $H$. Wagner. 2016. vegan: community ecology package. $R$ package version 2.0-7. R Foundation for Statistical Computing, Vienna, Austria.

Ortega-Álvarez, R., and I. MacGregor-Fors. 2009. Living in the big city: effects of urban land-use on bird community structure, diversity, and composition. Landscape and Urban Planning 90:189-195. http://dx.doi.org/10.1016/j.landurbplan.2008.11.003

Overbeck, G. E., S. C. Müller, A. Fidelis, J. Pfadenhauer, V. D. Pillar, C. C. Blanco, I. I. Boldrini, R. Both, and E. D. Forneck. 2007. Brazil's neglected biome: the South Brazilian Campos. Perspectives in Plant Ecology, Evolution and Systematics 9:101-116. http://dx.doi.org/10.1016/j.ppees.2007.07.005 
Pairo, P. E., L. M. Leveau, and M. I. Bellocq. 2017. Selección del hábitat de nidificación de la lechuza vizcachera (Athene cunicularia) en agroecosistemas de la Pampa Ondulada. Ecología Austral 27:375-384. http://dx.doi.org/10.25260/EA.17.27.3.0.465

Paruelo, J. M., J. P. Guerschman, G. Piñeiro, E. G. Jobbágy, S. R. Verón, G. Baldi, and S. Baeza. 2006. Cambios en el uso de la tierra en Argentina y Uruguay: marcos conceptuales para su análisis. Agrociencia 10:47-61.

Pauw, A., and K. Louw. 2012. Urbanization drives a reduction in functional diversity in a guild of nectar-feeding birds. Ecology and Society 17(2):27. http://dx.doi.org/10.5751/ES-04758-170227

Perkins, A. J., M. J. Whittingham, R. B. Bradbury, J. D. Wilson, A. J. Morris, and P. R. Barnett. 2000. Habitat characteristics affecting use of lowland agricultural grassland by birds in winter. Biological Conservation 95:279-294. http://dx.doi.org/10.1016/ S0006-3207(00)00042-2

Petchey, O. L., K. L. Evans, I. S. Fishburn, and K. J. Gaston. 2007. Low functional diversity and no redundancy in British avian assemblages. Journal of Animal Ecology 76:977-985. http://dx.doi. org/10.1111/j.1365-2656.2007.01271.x

Petchey, O. L., and K. J. Gaston. 2002. Functional diversity (FD), species richness and community composition. Ecology Letters 5:402-411. http://dx.doi.org/10.1046/j.1461-0248.2002.00339.x

Petchey, O. L., and K. J. Gaston. 2007. Dendrograms and measuring functional diversity. Oikos 116:1422-1426. http://dx. doi.org/10.1111/j.0030-1299.2007.15894.X

Petchey, O. L., A. Hector, and K. J. Gaston. 2004. How do different measures of functional diversity perform? Ecology 85:847-857. http://dx.doi.org/10.1890/03-0226

Peterjohn, B. G. 2003. Agricultural landscapes: can they support healthy bird populations as well as farm products? Auk 120:14-19. http://dx.doi.org/10.2307/4090136

Peterjohn, B., and J. R. Sauer. 1999. Population status of North American grassland birds from the North American Breeding Bird Survey. Pages 27-44 in P. D. Vickery and J. R. Herkert, editors. Ecology and conservation of grassland birds of the Western Hemisphere. Cooper Ornithological Society, Camarillo, California, USA.

Petit, L. J., D. R. Petit, D. G. Christian, and H. D. W. Powell. 1999. Bird communities of natural and modified habitats in Panama. Ecography 22:292-304. http://dx.doi.org/10.1111/ j.1600-0587.1999.tb00505.x

Phillips, H. R. P., T. Newbold, and A. Purvis. 2017. Land-use effects on local biodiversity in tropical forests vary between continents. Biodiversity and Conservation 26:2251-2270. http://dx. doi.org/10.1007/s10531-017-1356-2

Piha, M., J. Tiainen, J. Holopainen, and V. Vepsäläinen. 2007. Effects of land-use and landscape characteristics on avian diversity and abundance in a boreal agricultural landscape with organic and conventional farms. Biological Conservation 140:50-61. http://dx.doi.org/10.1016/j.biocon.2007.07.021

Pykälä, J. 2003. Effects of restoration with cattle grazing on plant species composition and richness of semi-natural grasslands.
Biodiversity and Conservation 12:2211-2226. http://dx.doi. org/10.1023/A:1024558617080

Ralph, C. J., G. R. Geupel, P. Pyle, T. E. Martin, D. F. DeSante, and B. Milá. 1996. Manual de métodos de campo para el monitoreo de aves terrestres. General Technical Report PSW-GTR-159-Web. Pacific Southwest Research Station, Forest Service, U.S. Department of Agriculture, Albany, California, USA.

R Core Team. 2018. R: a language and environment for statistical computing. R Foundation for Statistical Computing, Vienna, Austria. [online] URL: https://www.r-project.org

Renjifo, L. M. 2001. Effect of natural and anthropogenic landscape matrices on the abundance of subandean bird species. Ecological Applications 11:14-31. http://dx.doi.org/10.1890/1051-0761 (2001)011[0014:EONAAL]2.0.CO;2

Ricotta, C., M. DiNepi, D. Guglietta, and L. Celesti-Grapow. 2008. Exploring taxonomic filtering in urban environments. Journal of Vegetation Science 19:229-238. http://dx.doi. org/10.3170/2008-8-18363

Sala, O. E., F. S. Chapin III, J. J. Armesto, E. Berlow, J. Bloomfield, R. Dirzo, E. Huber-Sanwald, L. F. Huenneke, R. B. Jackson, A. Kinzig, R. Leemans, D. M. Lodge, H. A. Mooney, M. Oesterheld, N. L. Poff, M. T. Sykes, B. H. Walker, M. Walker, and D. H. Wall. 2000. Global biodiversity scenarios for the year 2100. Science 287:1770-1774. http://dx.doi.org/10.1126/science.287.5459.1770

Santoandré, S. 2017. Formación de ensambles biológicos: Influencia del contexto regional en la diversidad taxonómica y funcional de hormigas durante el ciclo forestal. Universidad de Buenos Aires, Buenos Aires, Argentina.

Schleuter, D., M. Daufresne, F. Massol, and C. Argillier. 2010. A user's guide to functional diversity indices. Ecological Monographs 80:469-484. http://dx.doi.org/10.1890/08-2225.1

Schulze, C. H., M. Waltert, P. J. A. Kessler, R. Pitopang, D. Veddeler, M. Mühlenberg, S. R. Gradstein, C. Leuschner, I. Steffan-Dewenter, and T. Tscharntke. 2004. Biodiversity indicator groups of tropical land-use systems: comparing plants, birds, and insects. Ecological Applications 14:1321-1333. http://dx.doi. org/10.1890/02-5409

Sekercioglu, C. H. 2006. Increasing awareness of avian ecological function. Trends in Ecology \& Evolution 21:464-471. http://dx.doi. org/10.1016/j.tree.2006.05.007

Seress, G., and A. Liker. 2015. Habitat urbanization and its effects on birds. Acta Zoologica Academiae Scientiarum Hungaricae 61:373-408. http://dx.doi.org/10.17109/AZH.61.4.373.2015

Silva, C. P., R. D. Sepúlveda, and O. Barbosa. 2016. Nonrandom filtering effect on birds: species and guilds response to urbanization. Ecology and Evolution 6:3711-3720. http://dx.doi. org/10.1002/ece3.2144

Silveira, L., and J. Alonso. 2009. Runoff modifications due to the conversion of natural grasslands to forests in a large basin in Uruguay. Hydrological Processes 23:320-329. http://dx.doi. org/10.1002/hyp.7156

Soriano, A., R. J. C. León, O. E. Sala, R. S. Lavado, V. A. Deregibus, M. A. Cauhepe, O. A. Scaglia, C. A. Velázquez, and 
J. H. Lemcoff. 1991. Río de la Plata Grasslands. Pages 367-407 in R. T. Coupland, editor. Natural grasslands: introduction and Western Hemisphere. Ecosystems of the World 8A. Elsevier, Amsterdam, The Netherlands.

Stotz, D. F., J. W. Fitzpatrick, T. A. Parker III, and D. K. Moskovits. 1996. Neotropical birds : ecology and conservation. University of Chicago Press, Chicago, Illinois, USA.

Suding, K. N., S. Lavorel, F. S. Chapin III, J. H. C. Cornelissen, S. Díaz, E. Garnier, D. Goldberg, D. U. Hooper, S. T. Jackson, and M.-L. Navas. 2008. Scaling environmental change through the community-level: a trait-based response-and-effect framework for plants. Global Change Biology 14:1125-1140. http://dx.doi. org/10.1111/j.1365-2486.2008.01557.x

Swenson, N. G., P. Anglada-Cordero, and J. A. Barone. 2011. Deterministic tropical tree community turnover: evidence from patterns of functional beta diversity along an elevational gradient. Proceedings of the Royal Society B: Biological Sciences 278:877-884. http://dx.doi.org/10.1098/rspb.2010.1369

Tilman, D. 2001. Functional diversity. Pages 109-120 in S. A. Levin, editor. Encyclopedia of biodiversity. Academic Press, San Diego, California, USA. http://dx.doi.org/10.1016/ B0-12-226865-2/00132-2

Tylianakis, J. M., A.-M. Klein, T. Lozada, and T. Tscharntke. 2006. Spatial scale of observation affects $\alpha, \beta$ and $\gamma$ diversity of cavity-nesting bees and wasps across a tropical land-use gradient. Journal of Biogeography 33:1295-1304. http://dx.doi.org/10.1111/ j.1365-2699.2006.01493.x

Vandewalle, M., F. de Bello, M. P. Berg, T. Bolger, S. Dolédec, F. Dubs, C. K. Feld, R. Harrington, P. A. Harrison, S. Lavorel, P. M. da Silva, M. Moretti, J. Niemelä, P. Santos, T. Sattler, J. P. Sousa, M. T. Sykes, A. J. Vanbergen, and B. A. Woodcock. 2010. Functional traits as indicators of biodiversity response to land use changes across ecosystems and organisms. Biodiversity and Conservation 19:2921-2947. http://dx.doi.org/10.1007/s10531-010-9798-9

Vega, E., G. Baldi, E. G. Jobbágy, and J. Paruelo. 2009. Land use change patterns in the Río de la Plata grasslands: the influence of phytogeographic and political boundaries. Agriculture, Ecosystems \& Environment 134:287-292. http://dx.doi.org/10.1016/ j.agee.2009.07.011

Verhulst, J., A. Báldi, and D. Kleijn. 2004. Relationship between land-use intensity and species richness and abundance of birds in Hungary. Agriculture, Ecosystems \& Environment 104:465-473. http://dx.doi.org/10.1016/j.agee.2004.01.043

Viglizzo, E. F., F. Lértora, A. J. Pordomingo, J. N. Bernardos, Z. E. Roberto, and H. Del Valle. 2001. Ecological lessons and applications from one century of low external-input farming in the pampas of Argentina. Agriculture, Ecosystems \& Environment 83:65-81. http://dx.doi.org/10.1016/S0167-8809(00)00155-9
Villéger, S., J. Ramos Miranda, D. Flores Hernández, and D. Mouillot. 2010. Contrasting changes in taxonomic vs. functional diversity of tropical fish communities after habitat degradation. Ecological Applications 20:1512-1522. http://dx.doi.org/10.1890/09-1310.1

WallisDeVries, M. F., J. P. Bakker, and S. E. Van Wieren. 1998. Grazing and conservation management. Kluwer Academic, Dordrecht, The Netherlands. http://dx.doi.org/10.1007/978-94-011-4391-2

Waltert, M., A. Mardiastuti, and M. Mühlenberg. 2004. Effects of land use on bird species richness in Sulawesi, Indonesia. Conservation Biology 18:1339-1346. http://dx.doi.org/10.1111/ j.1523-1739.2004.00127.x

Weyland, F., J. Baudry, and C. M. Ghersa. 2014. Rolling Pampas agroecosystem: which landscape attributes are relevant for determining bird distributions? Revista Chilena de Historia Natural 1:1-12.

Williams, N. S. G., J. W. Morgan, M. J. McDonnell, and M. A. McCarthy. 2005. Plant traits and local extinctions in natural grasslands along an urban-rural gradient. Journal of Ecology 93:1203-1213. http://dx.doi.org/10.1111/j.1365-2745.2005.01039. $\mathrm{x}$

Wilson, J. D., M. J. Whittingham, and R. B. Bradbury. 2005. The management of crop structure: a general approach to reversing the impacts of agricultural intensification on birds? Ibis 147:453-463. http://dx.doi.org/10.1111/j.1474-919x.2005.00440. $\mathrm{x}$

Xeno-canto Foundation. 2018. Xeno-canto: sharing bird sounds from around the world. Xeno-canto Foundation and Naturalis Biodiversity Center, Leiden, The Netherlands. [online] URL: https://www.xeno-canto.org

Zurita, G. A., and M. I. Bellocq. 2010. Spatial patterns of bird community similarity: bird responses to landscape composition and configuration in the Atlantic forest. Landscape Ecology 25:147-158. http://dx.doi.org/10.1007/s10980-009-9410-4

Zurita, G. A., and M. I. Bellocq. 2012. Bird assemblages in anthropogenic habitats: identifying a suitability gradient for native species in the Atlantic forest. Biotropica 44:412-419. http:// dx.doi.org/10.1111/j.1744-7429.2011.00821.x
Editor-in-Chief: Ryan Norris Subject Editor: Charles M.Francis
Sponsored by the Society of Canadian Ornithologists and Bird Studies Canada Parrainée par la Société des ornithologistes $d u$ Canada et Études d'oiseaux Canada

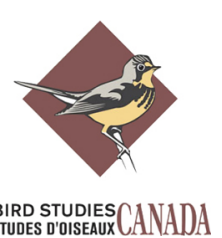




\section{Appendix 1}

Table A1.1 Trait data used in this study.

\begin{tabular}{|c|c|c|c|c|}
\hline \multicolumn{2}{|c|}{ MAIN GROUP/TRAIT TYPE } & ABBREVIATION & DESCRIPTION & REFERENCES \\
\hline \multirow{9}{*}{ FEEDING/DIET } & Frugivore & DIET_Frug & \multirow{9}{*}{$\begin{array}{l}\text { This trait } \\
\text { indicates } \\
\text { position in food } \\
\text { web and it } \\
\text { provides } \\
\text { information } \\
\text { about } \\
\text { ecosystem } \\
\text { services such as } \\
\text { population } \\
\text { regulation of } \\
\text { invertebrate and } \\
\text { vertebrate } \\
\text { species, } \\
\text { pollination and } \\
\text { seed dispersal. }\end{array}$} & \multirow{9}{*}{$\begin{array}{l}\text { Sekercioglu } \\
2006 \\
\text { Cofre et al. } \\
2007 \\
\text { Petchey et al. } \\
2007 \\
\text { Flynn et al. } \\
2009 \\
\text { Vandewalle et } \\
\text { al. } 2010 \\
\text { Luck et al. } \\
\text { 2012, } \\
\text { Leveau } 2013 \\
\text { Salgado-Negret } \\
\text { and Paz 2015 } \\
\text { Corbelli et al. } \\
\text { 2015 }\end{array}$} \\
\hline & Granivore & DIET_Gran & & \\
\hline & Carnivore & DIET_Carn & & \\
\hline & Carrion & DIET_Carr & & \\
\hline & Herbivore & DIET_Herb & & \\
\hline & Insectivore & DIET_Insec & & \\
\hline & $\begin{array}{l}\text { Another } \\
\text { invertebrates }\end{array}$ & DIET_Inver & & \\
\hline & Omnivore & DIET_Omn & & \\
\hline & Nectarivore & DIET_Nect & & \\
\hline \multirow{9}{*}{$\begin{array}{l}\text { FEEDING/FORAGING } \\
\text { SUBSTRATE }\end{array}$} & Ground & FOR_Grou & \multirow{9}{*}{$\begin{array}{l}\text { This trait } \\
\text { indicates where } \\
\text { birds conduct } \\
\text { their activities. } \\
\text { Species with } \\
\text { particular } \\
\text { foraging } \\
\text { behaviour } \\
\text { might be } \\
\text { impacted by } \\
\text { environmental } \\
\text { change. }\end{array}$} & \multirow{9}{*}{$\begin{array}{l}\text { Martin \& } \\
\text { Possingham } \\
2005 \\
\text { Petchey et al. } \\
2007 \\
\text { Flynn et al. } \\
2009 \\
\text { Luck et al. } \\
2012 \\
\text { Leveau 2013 } \\
\text { Salgado-Negret } \\
\text { and Paz 2015 } \\
\text { Corbelli et al. } \\
\text { 2015 }\end{array}$} \\
\hline & Shrub & FOR_Shru & & \\
\hline & Trees & FOR_Tree & & \\
\hline & Air & FOR_Air & & \\
\hline & Water & FOR_Wat & & \\
\hline & $\begin{array}{l}\text { Forage } \\
\text { throughout }\end{array}$ & FOR_Thro & & \\
\hline & Ground & FOR_Grou & & \\
\hline & Shrub & FOR_Shru & & \\
\hline & Trees & FOR_Tree & & \\
\hline \multirow{3}{*}{ FEEDING/BODY SIZE } & Less $100 \mathrm{gr}$ & BODY_Small & \multirow{3}{*}{$\begin{array}{l}\text { Body size is } \\
\text { strongly related } \\
\text { to a range of } \\
\text { other traits in } \\
\text { birds including } \\
\text { metabolic rate, } \\
\text { foraging } \\
\text { behaviour, } \\
\text { longevity and } \\
\text { home-range } \\
\text { size. }\end{array}$} & \multirow{3}{*}{$\begin{array}{l}\text { Cofre et al. } \\
2007 \text { Feeley et } \\
\text { al. } 2007 \\
\text { Petchey et al. } \\
2007 \\
\text { Flynn et al. } \\
2009 \\
\text { Vandewalle et } \\
\text { al. } 2010 \\
\text { Luck et al. } \\
2012 \\
\text { Salgado Negret } \\
\text { and Paz 2015 } \\
\text { Corbelli et al. } \\
\text { 2015 }\end{array}$} \\
\hline & $100-500 \mathrm{gr}$ & BODY_Med & & \\
\hline & More $500 \mathrm{gr}$ & BODY_Larg & & \\
\hline
\end{tabular}




\section{Appendix 1}

Table A1.1 continued.

\begin{tabular}{|c|c|c|c|c|}
\hline \multirow{3}{*}{ BREEDING/CLUTCH SIZE } & One egg & CLUT_Small & \multirow{3}{*}{$\begin{array}{l}\text { Species with } \\
\text { low } \\
\text { reproductive } \\
\text { rates (e.g. small } \\
\text { clutch size, } \\
\text { infrequent } \\
\text { breeding and } \\
\text { low annual } \\
\text { productivity) } \\
\text { and low } \\
\text { survival rates } \\
\text { are less resilient } \\
\text { to } \\
\text { environmental } \\
\text { change (i.e. } \\
\text { have a reduced } \\
\text { capacity to } \\
\text { recover from } \\
\text { disturbances) } \\
\text { than those with } \\
\text { high rates. }\end{array}$} & \multirow{3}{*}{$\begin{array}{l}\text { Cofre et al. } \\
2007 \\
\text { Petchey et al. } \\
2007 \\
\text { Luck et al } 2012 \\
\text { Corbelli et al. } \\
2015\end{array}$} \\
\hline & $\begin{array}{l}\text { Two to three } \\
\text { eggs }\end{array}$ & CLUT_Med & & \\
\hline & $\begin{array}{l}\text { More than } \\
\text { three eggs }\end{array}$ & CLUT_Larg & & \\
\hline \multirow{10}{*}{$\begin{array}{l}\text { BREEDING/NESTING } \\
\text { HABITATS }\end{array}$} & Ground & NEST_Grou & \multirow{10}{*}{$\begin{array}{l}\text { This trait } \\
\text { indicates } \\
\text { sensitivity to } \\
\text { different habitat } \\
\text { changes that } \\
\text { affect the } \\
\text { nesting habitats' } \\
\text { availability. }\end{array}$} & \multirow{10}{*}{$\begin{array}{l}\text { Sekercioglu } \\
2006 \\
\text { Vandewalle et } \\
\text { al.2010 } \\
\text { Luck et al } 2012 \\
\text { Leveau } 2013\end{array}$} \\
\hline & Water & NEST_Wat & & \\
\hline & Grass & NEST_Gras & & \\
\hline & Shrub & NEST_Shru & & \\
\hline & Trees & NEST_Tree & & \\
\hline & $\begin{array}{l}\text { Natural } \\
\text { cavities }\end{array}$ & NEST_NatCav & & \\
\hline & $\begin{array}{l}\text { Nest of } \\
\text { another } \\
\text { species }\end{array}$ & NEST_Anoth & & \\
\hline & Parasitic & NEST_Par & & \\
\hline & Various & NEST_Var & & \\
\hline & $\begin{array}{l}\text { Buildings or } \\
\text { human } \\
\text { constructions }\end{array}$ & NEST_Build & & \\
\hline \multirow{2}{*}{$\begin{array}{l}\text { BREEDING/MIGRATORY } \\
\text { STATUS }\end{array}$} & Resident & MS_R & \multirow{2}{*}{$\begin{array}{l}\text { This trait might } \\
\text { influence large- } \\
\text { scale cycling of } \\
\text { nutrients and } \\
\text { the delivery of } \\
\text { services across } \\
\text { broad regions } \\
\text { and determines }\end{array}$} & \multirow{2}{*}{$\begin{array}{l}\text { Cofre et al. } \\
2007 \\
\text { López-Lanús et } \\
\text { al. } 2008 \\
\text { Luck et al. } \\
2012 \\
\text { Leveau } 2013 \\
\text { Corbelli et al. }\end{array}$} \\
\hline & Migratory A & MS_A & & \\
\hline
\end{tabular}




\section{Appendix 1}

Table A1.1 continued.

\begin{tabular}{|c|c|c|c|c|}
\hline & Migratory B & MS_B & $\begin{array}{l}\text { seasonal change } \\
\text { in community } \\
\text { composition. }\end{array}$ & 2015 \\
\hline & Migratory C & MS_C & & \\
\hline HABITAT/NUMBER OF & One to three & NHU_Small & $\begin{array}{l}\text { Habitat } \\
\text { generalists are } \\
\text { more resilient } \\
\text { to } \\
\text { environmental }\end{array}$ & $\begin{array}{l}\text { López-Lanús et } \\
\text { al. } 2008 \\
\text { Luck et al. }\end{array}$ \\
\hline & $\begin{array}{l}\text { More than } \\
\text { three }\end{array}$ & NHU_Big & $\begin{array}{l}\text { can choose } \\
\text { from a variety } \\
\text { of habitats, than } \\
\text { those which are } \\
\text { specialist. }\end{array}$ & $\begin{array}{l}\text { Corbelli et al. } \\
2015\end{array}$ \\
\hline & Forest & HAB_Forest & & Stotz et al. \\
\hline & Shrub & HAB_Shru & This trait is & 1996 \\
\hline & $\begin{array}{l}\text { Rural areas } \\
\text { and towns }\end{array}$ & HAB_Rur & $\begin{array}{l}\text { to the principal } \\
\text { habitat where }\end{array}$ & $\begin{array}{l}2007 \\
\text { Feeley et al. }\end{array}$ \\
\hline $\begin{array}{l}\text { HABITAT/PRIMARY } \\
\text { HABITAT }\end{array}$ & Urban areas & HAB_Urb & $\begin{array}{l}\text { the different } \\
\text { snecies can be }\end{array}$ & $\begin{array}{l}2007 \\
\text { Lónez-Lanús et }\end{array}$ \\
\hline & Wetlands & HAB_Wet & $\begin{array}{l}\text { found. This } \\
\text { includes human }\end{array}$ & $\begin{array}{l}\text { al. } 2008 \\
\text { Vandewalle et }\end{array}$ \\
\hline & Grassland & HAB_Grass & $\begin{array}{l}\text { modified } \\
\text { habitats. }\end{array}$ & $\begin{array}{l}\text { al. } 2010 \\
\text { Corbelli et al. }\end{array}$ \\
\hline & $\begin{array}{l}\text { No primary } \\
\text { habitat }\end{array}$ & HAB_Many & & 2015 \\
\hline & Favorable & SENS_Fav & $\begin{array}{l}\text { This trait is } \\
\text { related to the } \\
\text { way in which } \\
\text { the different }\end{array}$ & \\
\hline VULNERABILITY/ & Low & SENS_Low & $\begin{array}{l}\text { the anthropic } \\
\text { processes of } \\
\text { modification, } \\
\text { replacement }\end{array}$ & $\begin{array}{l}\text { Stotz et al } 1996 \\
\text { López-Lanús et }\end{array}$ \\
\hline DISTURBANCE & Medium & SENS_Med & $\begin{array}{l}\text { environments. } \\
\text { Some might } \\
\text { benefit from }\end{array}$ & $\begin{array}{l}\text { Cobelli et al. } \\
2015\end{array}$ \\
\hline & High & SENS_High & $\begin{array}{l}\text { disturbance or } \\
\text { be affected by it } \\
\text { in a low, } \\
\text { medium or high } \\
\text { intensity. }\end{array}$ & \\
\hline $\begin{array}{l}\text { VULNERABILITY/ } \\
\text { ABUNDANCE }\end{array}$ & Common & ABUND_Com & $\begin{array}{l}\text { Population } \\
\text { abundance is }\end{array}$ & $\begin{array}{l}\text { Stotz et al. } \\
1996\end{array}$ \\
\hline
\end{tabular}




\section{Appendix 1}

Table A1.1 continued.

\begin{tabular}{|c|c|c|c|c|}
\hline & Frequent & ABUND_Freq & \multirow{2}{*}{$\begin{array}{l}\text { strongly related } \\
\text { to the species' } \\
\text { risk of } \\
\text { extinction. }\end{array}$} & \multirow{2}{*}{$\begin{array}{l}\text { Cofre et al. } \\
2007 \\
\text { Feeley et al. } \\
2007 \\
\text { López-Lanús et } \\
\text { al. } 2008\end{array}$} \\
\hline & Limited & ABUND_Lim & & \\
\hline \multirow{4}{*}{$\begin{array}{l}\text { VULNERABILITY/ } \\
\text { DISTRIBUTION }\end{array}$} & Cosmopolitan & DIST_Cosm & \multirow{4}{*}{$\begin{array}{l}\text { Species with } \\
\text { very restricted } \\
\text { distributions } \\
\text { have higher risk } \\
\text { of extinction } \\
\text { than those with } \\
\text { broader ones. }\end{array}$} & \multirow{4}{*}{$\begin{array}{l}\text { Gillespie } 2002 \\
\text { Cofre et al. } \\
2007 \\
\text { Feeley et al. } \\
2007 \\
\text { López-Lanús et } \\
\text { al. } 2008\end{array}$} \\
\hline & Neotropical & DIST_Neo & & \\
\hline & $\begin{array}{l}\text { South } \\
\text { America }\end{array}$ & DIST_SouAme & & \\
\hline & $\begin{array}{l}\text { South of } \\
\text { South } \\
\text { America }\end{array}$ & DIST_South & & \\
\hline
\end{tabular}

\section{LITERATURE CITED}

Cofre, H. L., K. Böhning-Gaese, and P. A. Marquet. 2007. Rarity in Chilean forest birds: Which ecological and life-history traits matter?: Biodiversity research. Diversity and Distributions 13:203-212. doi: 10.1111/j.1472-4642.2006.00312.x.

Corbelli, J. M., G. A. Zurita, J. Filloy, J. P. Galvis, N. I. Vespa, and I. Bellocq. 2015. Integrating taxonomic, functional and phylogenetic beta diversities: Interactive effects with the biome and land use across taxa. PLOS ONE 10:1-17. doi:

10.1371/journal.pone.0126854.

Feeley, K. J., T. W. Gillespie, D. J. Lebbin, and H. S. Walter. 2007. Species characteristics associated with extinction vulnerability and nestedness rankings of birds in tropical forest fragments. Animal Conservation 10:493-501. doi: 10.1111/j.14691795.2007.00140.x.

Flynn, D. F. B., M. Gogol-Prokurat, T. Nogeire, N. Molinari, B. T. Richers, B. B. Lin, N. Simpson, M. M. Mayfield, and F. DeClerck. 2009. Loss of functional diversity under land use intensification across multiple taxa. Ecology Letters 12:22-33. doi: 10.1111/j.1461-0248.2008.01255.x.

Gillespie, T. W. 2002. Latitudinal extent and natural history characteristics of birds in Nicaragua. Global Ecology and Biogeography 11:411-417. doi: 10.1046/j.1466822x.2002.00295.x.

Leveau, L. M. 2013. Bird traits in urban-rural gradients: how many functional groups are there? Journal of Ornithology 154:655-662. doi: 10.1007/s10336-012-0928-x.

López-Lanús, B., P. Grilli, A. S. Di Giacomo, E. E. Coconier, and R. Banchs. 2008. Categorización de las aves de la Argentina según su estado de conservaciónAves Argen. 


\section{Appendix 1}

Table A1.1 continued.

Luck, G. W., S. Lavorel, S. Mcintyre, and K. Lumb. 2012. Improving the application of vertebrate trait-based frameworks to the study of ecosystem services. Journal of Animal Ecology 81:1065-1076. doi: 10.1111/j.1365-2656.2012.01974.x.

Martin, T. G., and H. P. Possingham. 2005. Predicting the impact of livestock grazing on birds using foraging height data. Journal of Applied Ecology 42:400-408. doi: 10.1111/j.1365-2664.2005.01012.x.

Petchey, O. L., K. L. Evans, I. S. Fishburn, and K. J. Gaston. 2007. Low functional diversity and no redundancy in British avian assemblages. Journal of Animal Ecology 76:977-985. doi: 10.1111/j.1365-2656.2007.01271.x.

Salgado-Negret, B. and H. Paz. 2015. Escalando de los rasgos funcionales a procesos poblacionales, comunitarios y ecosistémicos. La ecología funcional como aproximación al estudio, manejo y conservación de la biodiversidad: protocolos y aplicaciones (B. Salgado-Negret, Editor). Instituto de Investigación de Recursos Biológicos Alexander von Humboldt, Bogotá, Colombia, 12-35.

Sekercioglu, C. H. 2006. Increasing awareness of avian ecological function. Trends in Ecology and Evolution 21:464-471. doi: 10.1016/j.tree.2006.05.007.

Stotz, D. F., J. W. Fitzpatrick, T. A. Parker III, and D. K. Moskovits. 1996. Neotropical birds : ecology and conservation. The University of Chicago Press.

Vandewalle, M., F. de Bello, M. P. Berg, T. Bolger, S. Dolédec, F. Dubs, C. K. Feld, R. Harrington, P. A. Harrison, S. Lavorel, P. M. da Silva, M. Moretti, J. Niemelä, P. Santos, T. Sattler, J. P. Sousa, M. T. Sykes, A. J. Vanbergen, and B. A. Woodcock. 2010. Functional traits as indicators of biodiversity response to land use changes across ecosystems and organisms. Biodiversity and Conservation 19:2921-2947. doi: 10.1007/s10531-010-9798-9. 


\section{Appendix 2}

Figures of non-metric multidimensional scaling (NMDS) analysis of habitat type sites and protected areas based on the similarity of traits.

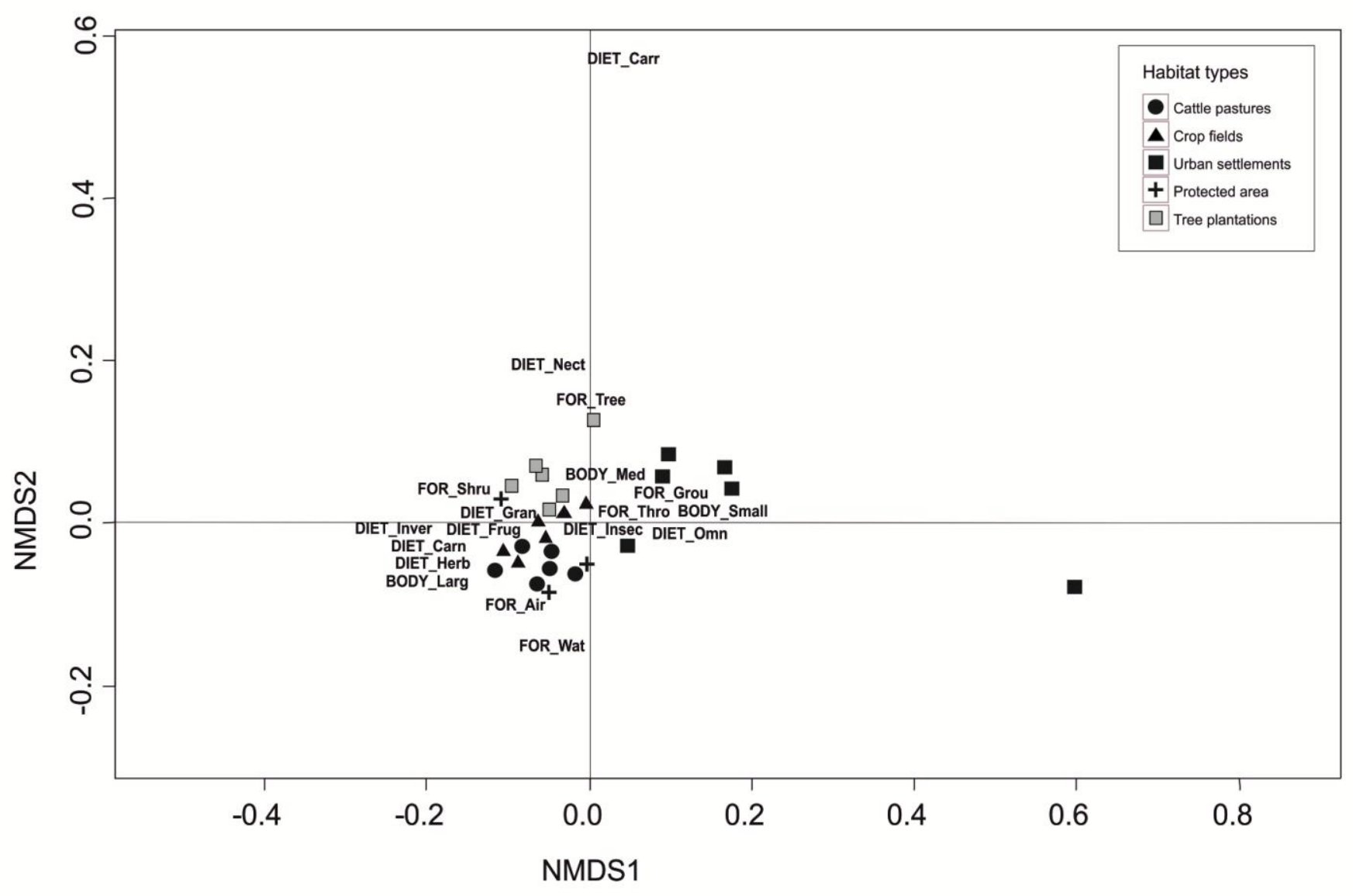

Fig. A2.1. Non-metric multidimensional scaling (NMDS) analysis of habitat type sites and protected areas based on the similarity of traits. The function adds traits scores to the site ordination. Traits groups are shown in four separated figures. This figure corresponds to feeding habits. Acronyms of categorical traits are in Appendix 1. 


\section{Appendix 2}

Figures of non-metric multidimensional scaling (NMDS) analysis of habitat type sites and protected areas based on the similarity of traits.

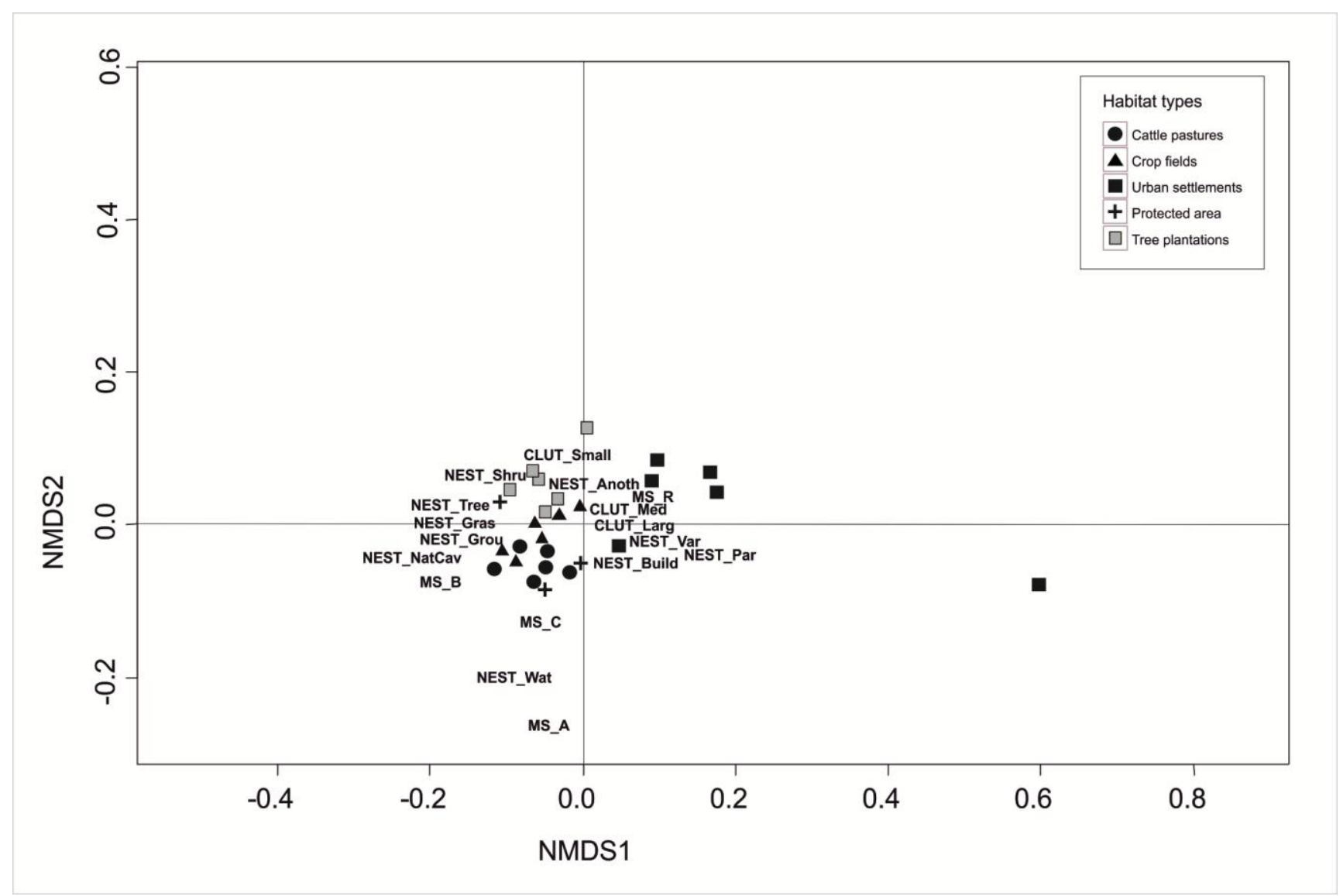

Fig. A2.2. Non-metric multidimensional scaling (NMDS) analysis of habitat type sites and protected areas based on the similarity of traits. The function adds traits scores to the site ordination. Traits groups are shown in four separated figures. This figure corresponds to breeding habits. Acronyms of categorical traits are in Appendix 1. 


\section{Appendix 2}

Figures of non-metric multidimensional scaling (NMDS) analysis of habitat type sites and protected areas based on the similarity of traits.

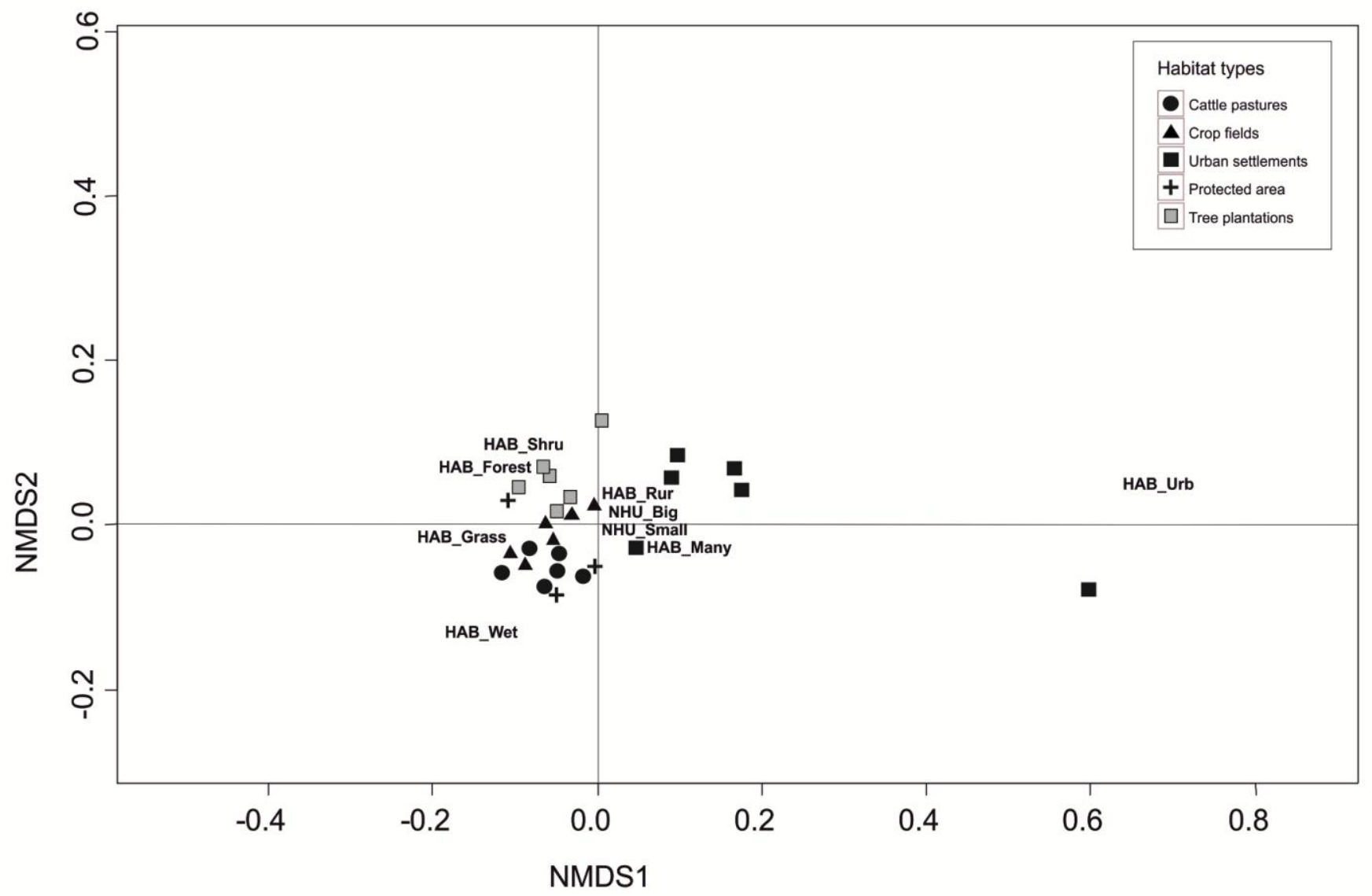

Fig. A2.3. Non-metric multidimensional scaling (NMDS) analysis of habitat type sites and protected areas based on the similarity of traits. The function adds traits scores to the site ordination. Traits groups are shown in four separated figures. This figure corresponds to habitat use. Acronyms of categorical traits are in Appendix 1. 


\section{Appendix 2}

Figures of non-metric multidimensional scaling (NMDS) analysis of habitat type sites and protected areas based on the similarity of traits.

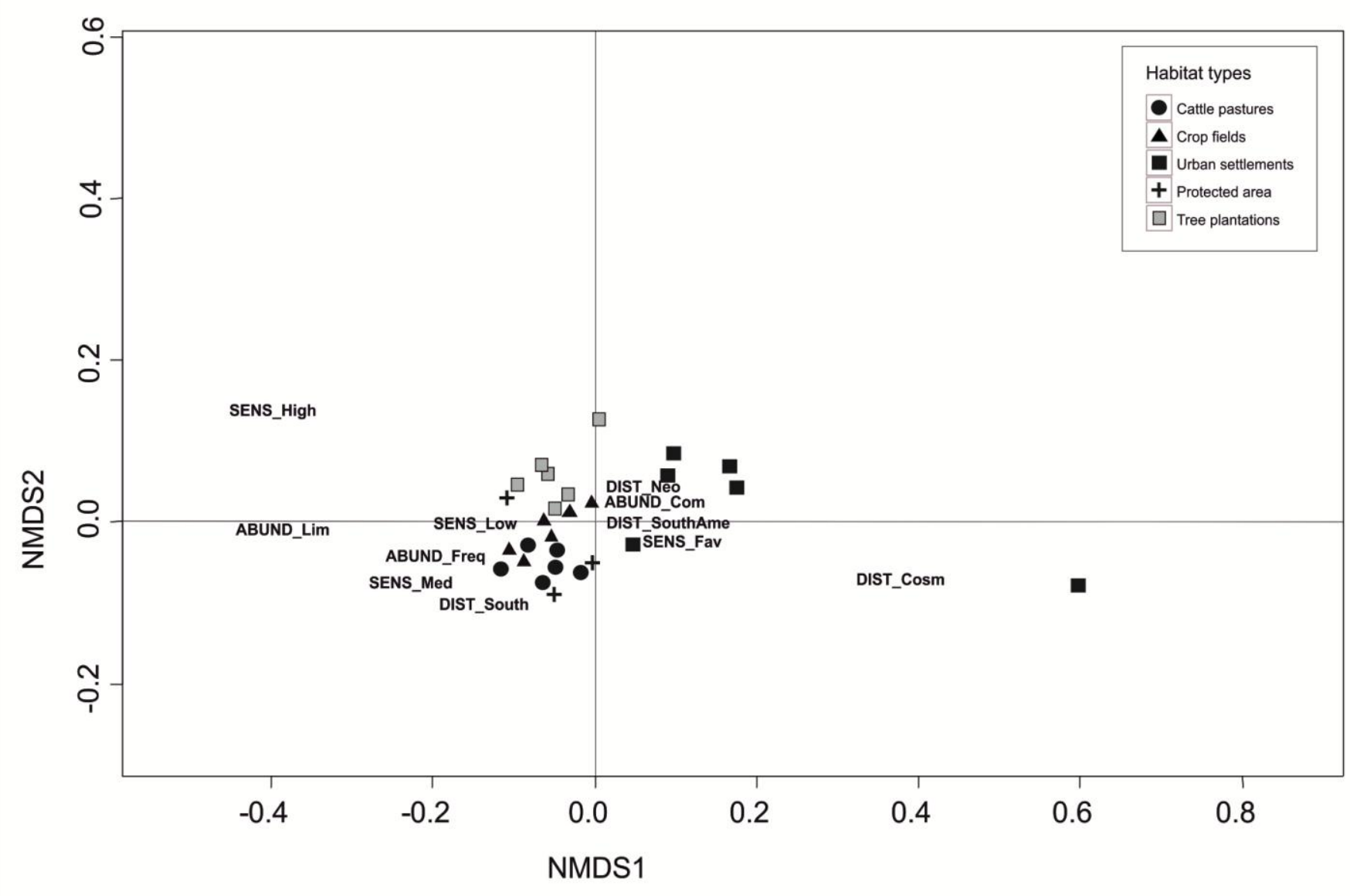

Fig. A2.4. Non-metric multidimensional scaling (NMDS) analysis of habitat type sites and protected areas based on the similarity of traits. The function adds traits scores to the site ordination. Traits groups are shown in four separated figures. This figure corresponds to vulnerability. Acronyms of categorical traits are in Appendix 1. 
Appendix 3. Table of number of study sites in each habitat type where the species was detected

Please click here to download file 'appendix3.xlsx'. 
Avian Conservation and Ecology 14(1): 1

http://www.ace-eco.org/vol14/iss1/art1/

Appendix 4. Table of species and traits

Please click here to download file 'appendix4.xlsx'. 